\title{
Rock mechanics tools for mining in high stress ground conditions at Nickel Rim South Mine
}

\author{
A Jalbout Sudbury Integrated Nickel Operations, A Glencore Company, Canada \\ B Simser Sudbury Integrated Nickel Operations, A Glencore Company, Canada
}

\begin{abstract}
Nickel Rim South Mine of Sudbury Integrated Nickel Operations (Sudbury INO), A Glencore Company, has challenging ground conditions related to: complex geological structure; depth of the current orebody (from 1,160-1,710 m below surface); the mine layout where two sills were required; the draw point pillar geometry; and the type of ground support that has been used during the project ramp up phase.

In order to manage the risk associated with mining while these conditions exist, sophisticated and state of the art tools have been used to predict the ground response to mining activities. The overall mine layout and rock mechanics issues are discussed. Analysis techniques using high resolution seismic monitoring, non-linear numerical models, cad/database linked models to assess geotechnical hazard, and high end microseismic analysis software are shown as examples.
\end{abstract}

\section{Introduction}

Nickel Rim South Mine of Sudbury INO is located along the northeast limb of the Sudbury Basin, between the Sudbury Regional Airport and Lake Wanapitei. The deposit was discovered in 2001 and has been fast tracked to full production in 2010. The mining method is sublevel open stoping with cemented hydraulic tailings fill at a production rate of $1.25 \mathrm{~m}$ t per annum.

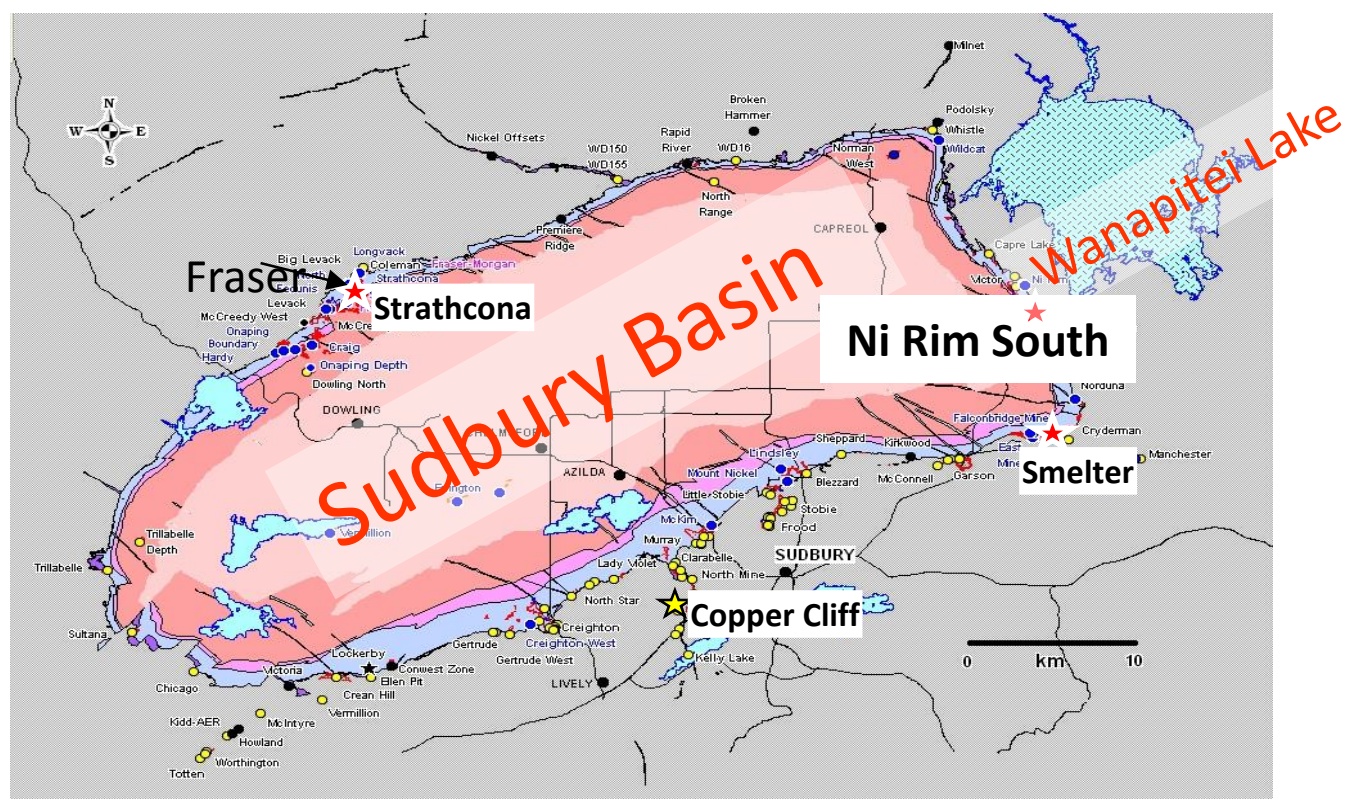

Figure 1 Sudbury igneous complex with Nickel Rim South Mine on the northeast limb

\section{$2 \quad$ Mine deposit}

Three principal mineralised zones comprising the Nickel Rim South resource together cover an area that extends approximately $720 \mathrm{~m}$ along a northwest to southeast corridor. The three zones are the main contact zone (CT), a second contact zone (CTII), and a main footwall zone (FW) (Figure 2). 


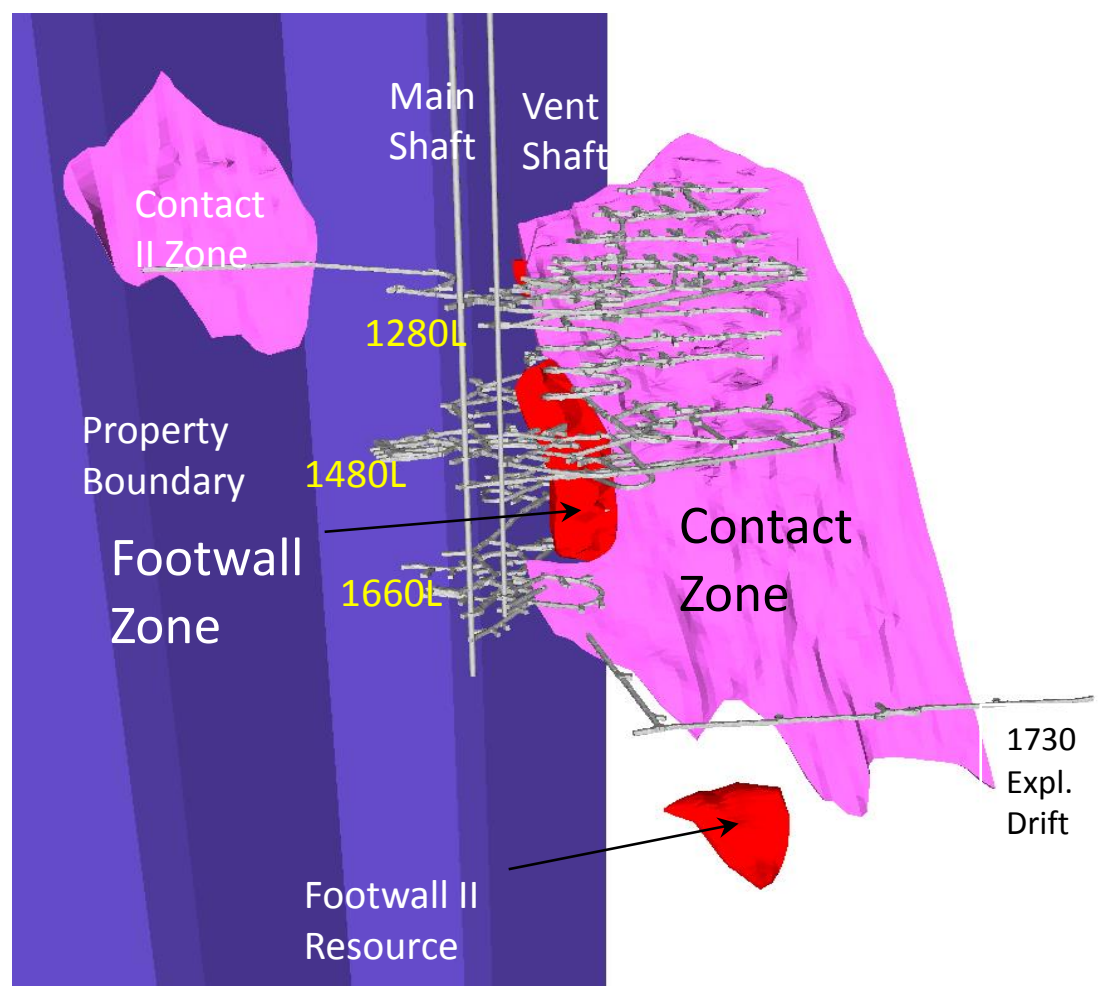

\section{Figure 2 Longitudinal view of the geological model for Nickel Rim South Mine. The top of the deposit is approximately $1,150 \mathrm{~m}$ below surface, with the current mine plan extending down to $1,710 \mathrm{~m}$. Exploration is ongoing for deeper targets, for example the footwall II resource is sub $2,000 \mathrm{~m}$}

The contact zones are nickel rich orebodies, while the footwall zones have copper, nickel, and precious metals (platinum groups with some gold and silver). Level names refer to depth below surface in metres. The twin shaft access utilises a hoisting shaft down to $1,730 \mathrm{~m}$ and the second egress is from the ventilation shaft extending down to $1,700 \mathrm{~m}$ below surface.

\subsection{Contact zone}

Contact mineralisation at Nickel Rim South consists of massive and semi massive nickel bearing sulphides. Access to the steeply dipping zone $\left(\sim 70^{\circ}\right)$ is from the hanging wall. The rock units are summarised in Table 1. Access development is within norites (DNOR and FNOR) with crosscuts coming through breccia units into the sulphides. In general the hanging wall ore contact is grade driven, with a low grade disseminated sulphide halo, while the footwall tends to have a sharp contact. All the rock units are good quality (geological strength index GSI>65), but they are more prominently jointed than the footwall units (GSI 80).

\section{$2.2 \quad$ Footwall zone}

The style of Nickel Rim South footwall mineralisation compares closely with other Sudbury footwall deposits (often referred to as copper zones), the notable exception is the close proximity to the contact zone. The two types of mineralisation are often separated by a few hundred metres, but at Nickel Rim South they merge together at around 1,320 m depth and are only separated by a few tens of metres below that horizon. Mineralisation is closely associated with a zone of Sudbury Breccia (SDBX) and the footwall development is in a Felsic Gneiss unit (FGN). Both are fine grained, hard granitic rocks, although very competent, can be prone to rockbursting at depth. The copper sulphides occur in an erratic assemblage of veins ranging from a few centimeters to several metres thick. Overall they lie within a steeply dipping $\left(70^{\circ}\right)$ mineralised envelop which is also mined using blasthole stoping. A large strength contrast exists between 
the complex copper veins and the host rock (Table 1), with the veins fracturing and deforming preferentially. The footwall zones generate much more seismic activity relative to the nickel ore (Simser \& Pritchard 2010).

\subsection{Underground structural mapping}

The mine has used in-cycle fibre reinforced shotcrete for a large portion of the development (mesh is also used in some areas) so geologists accompany the mining shift schedule to ensure a high percentage (>90\%) of the development is adequately mapped. Jointing, lithology, and structure are all mapped using tablet computers, and a structural interpretation is conducted supplemented by diamond drill core information. The joint data is routinely used for wedge analysis and the stability graph method for stope design (Simser et al. 2014).

\section{$2.4 \quad$ Faults}

The 3D structural model contains three orientations of brittle faults. To date no ductile shear zones have been encountered. The brittle fault orientations are:

- North-south trending, steeply-dipping faults (fault set 1 ).

- Low angle, gently dipping faults (fault set 2 ).

- Northeast and southeast striking, steeply dipping faults associated with narrow (1-5 cm thick) aplite dykes (fault set 3).

All three fault orientations are associated with chloritic alteration, bornite mineralisation (when in proximity to sulphide mineralisation) and quartz carbonate veining.

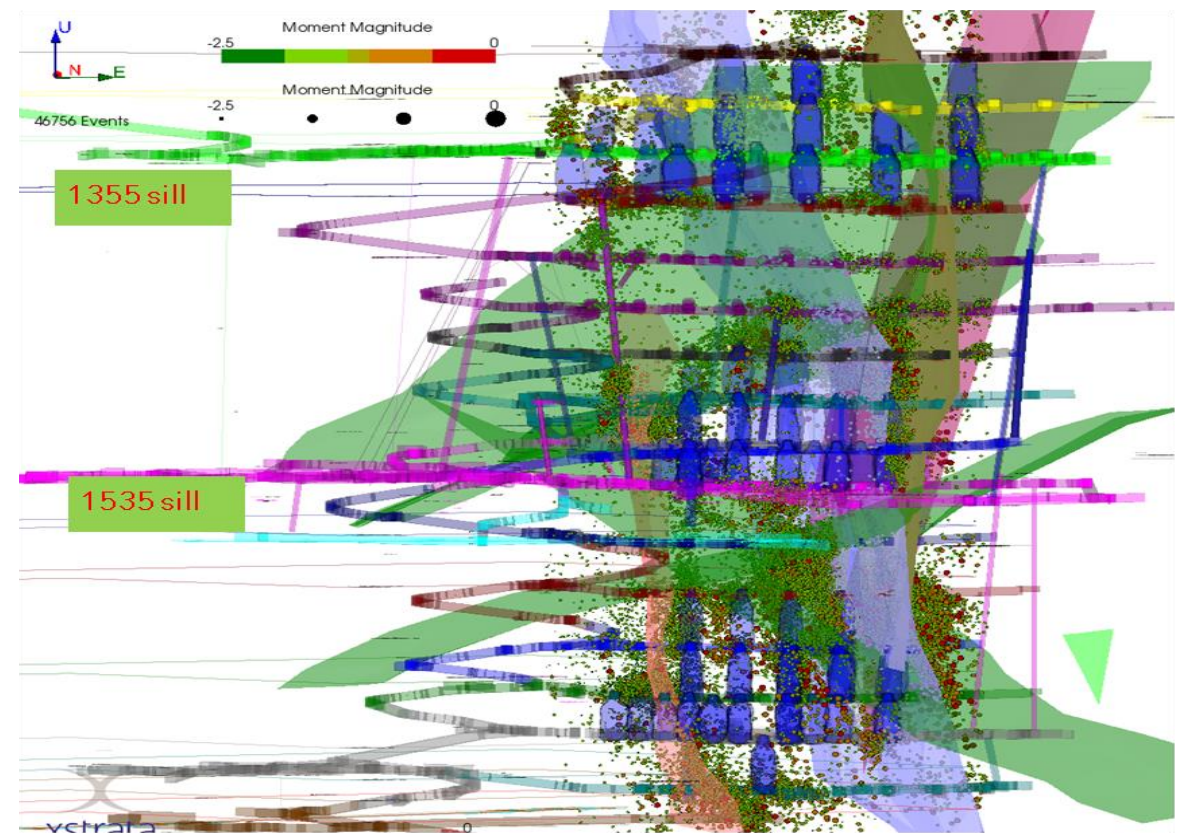

Figure 3 Longitudinal view of the mining areas with mined stopes show by blue (cavity monitoring survey images), $5 \times 5.5 \mathrm{~m}$ development tunnels, seismicity over a one year period shown by small coloured spheres, and the fault model shown by translucent pseudo planar surfaces

The faulting has clearly impacted observed seismicity, by both fault slip type events and by acting as a stress channel. It is often observed that increased seismicity occurs in the ground between an open stope and a major fault plane. The faults effectively funnel the stress flow into a smaller volume. Drill hole notching or raisebore breakouts often show stress directions parallel to the local faults. The mine wide modelling (see following sections) takes this into account by including the fault surfaces and calibrating the 
model results with the observed seismicity (Beck et al. 2012). The seismic response to stoping is often asymmetric, and can only be 'mimicked' by the model if fault movement is considered.

\subsection{Diabase dykes}

Nickel Rim South diabase dykes are generally fine grained and very strong (isolated samples have been tested to $415 \mathrm{MPa}$ unconfined compressive strength (UCS)). They have been associated with some strainbursting, and are considered a long term risk due to the fact that a very high mining induced stress may be required to drive them to failure (as the overall extraction increases, these dykes may cause more bursting problems in the future). Most of the dykes occur as brecciated fragments (highly variable size, 10s of $\mathrm{cm}$ to $10 \mathrm{~s}$ of $\mathrm{m}$ ), predominantly in the footwall of the orebody.

\subsection{Geotechnical data/in situ stress}

Rock strength data has been obtained from both UCS (including some triaxial testing) and point load testing of diamond drill core. Typical rock strength values and rock mass ratings for the mine are summarised in Table 1.

\section{Table 1 Typical rock mass parameters. Rock units are common to several Sudbury Mines, but differences in overall character are sometimes noted in different portions of the basin despite having the same mapping name}

\begin{tabular}{cccccccc}
\hline & \multicolumn{2}{c}{$\begin{array}{c}\text { UCS } \\
\text { (MPa) }\end{array}$} & \multicolumn{5}{c}{ Rock quality tunnelling index } \\
Q typical range \\
Rock type & $\begin{array}{c}\text { Point } \\
\text { Load }\end{array}$ & $\begin{array}{c}\text { Core } \\
\text { Test }\end{array}$ & RQD* & Jn & Jr & Ja & Jw \\
FGN & 178 & 250 & $75-100$ & $6-9$ & $1-3$ & 1 & 1 \\
FNOR & 263 & 215 & $75-100$ & $6-9$ & $1-3$ & 1 & 1 \\
Late granite breccia (LGBX) & 190 & 206 & $75-100$ & $6-9$ & $1-3$ & 1 & 1 \\
SDBX & 200 & 383 & $75-100$ & $6-9$ & $1-3$ & 1 & 1 \\
Semi massive sulphide Ni & 153 & 196 & $75-100$ & $6-9$ & $0.5-3$ & 1 & 1 \\
Massive sulphide Ni & 84 & 89 & $75-100$ & $6-9$ & $0.5-3$ & $1-3$ & 1 \\
High grade copper & 49 & 28 & $50-75$ & $6-9$ & $0.5-3$ & $1-3$ & 1 \\
Dark norite breccia & 229 & 160 & $75-100$ & $6-9$ & $0.5-3$ & $1-3$ & 1 \\
Diabase & 290 & - & $75-100$ & $6-9$ & $1-3$ & 1 & 1 \\
Dark norite & 234 & 160 & $75-100$ & $6-9$ & $1-3$ & 1 & 1 \\
Gabbo & 284 & 279 & $75-100$ & $6-9$ & $1-3$ & 1 & 1 \\
Grand norite & 240 & 226 & $75-100$ & $6-9$ & $1-3$ & 1 & 1 \\
\hline
\end{tabular}

${ }^{*} \mathrm{RQD}=$ rock quality designation

Stress measurements have been conducted with both over coring (CSIRO HI cell tests) and the acoustic emission technique $(A E)$. The $A E$ results were plausible and fit well with field observations. The stress results from the $A E$ test are: $\sigma_{1}$ horizontal strike orientated (generally east-west) $1.6^{*} \sigma_{\text {vertical; }} \sigma_{2}$ horizontal dip direction (north-south) $1.3^{*} \sigma_{\text {vertical, }}$ and $\sigma_{3}=\sigma_{\text {vertical }}=$ weight of overburden $(0.026 \mathrm{MPa} / \mathrm{m}$ depth). Local stress rotations have been noted near geological structure (overbreak profiles and borehole breakouts). 


\section{$3 \quad$ Stope design and sequencing}

\subsection{Contact zone stope and sequence design}

The contact or nickel zone above $1320 \mathrm{~L}$ is laid out as a primary/secondary/tertiary sequence, with the primaries being $15 \mathrm{~m}$ wide. Tertiary stopes were originally designed at $10 \mathrm{~m}$ width, and the secondaries as $15 \mathrm{~m}$ wide. However a change was made to $12.5 \mathrm{~m}$ widths for both secondary and tertiary stopes to improve ground integrity of the tertiary stopes.
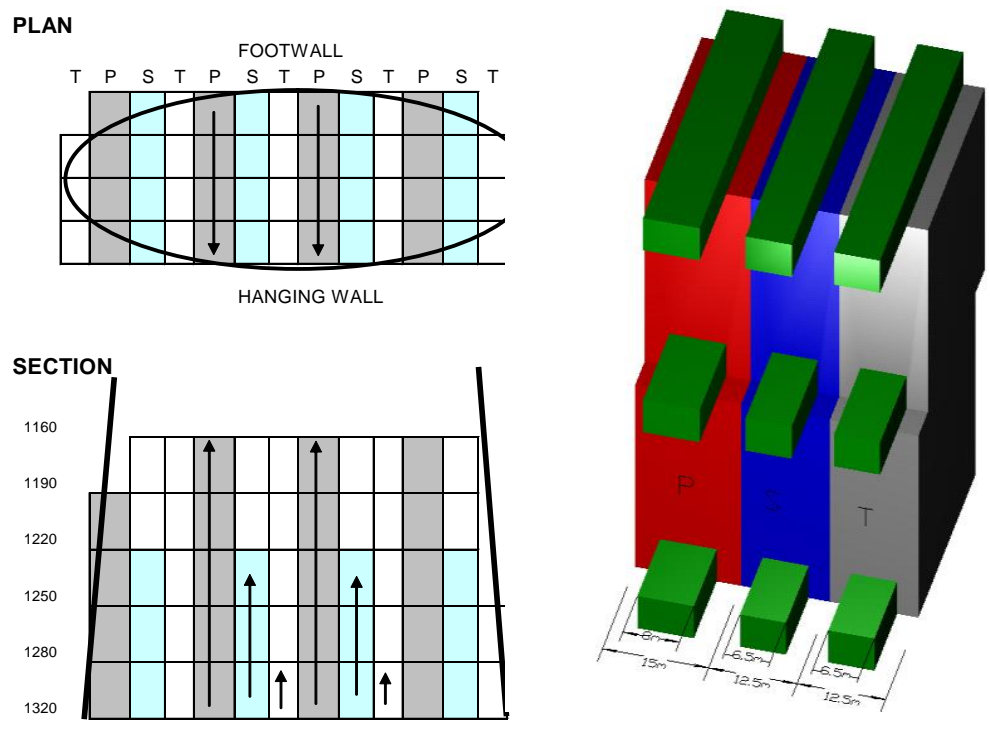

(a)

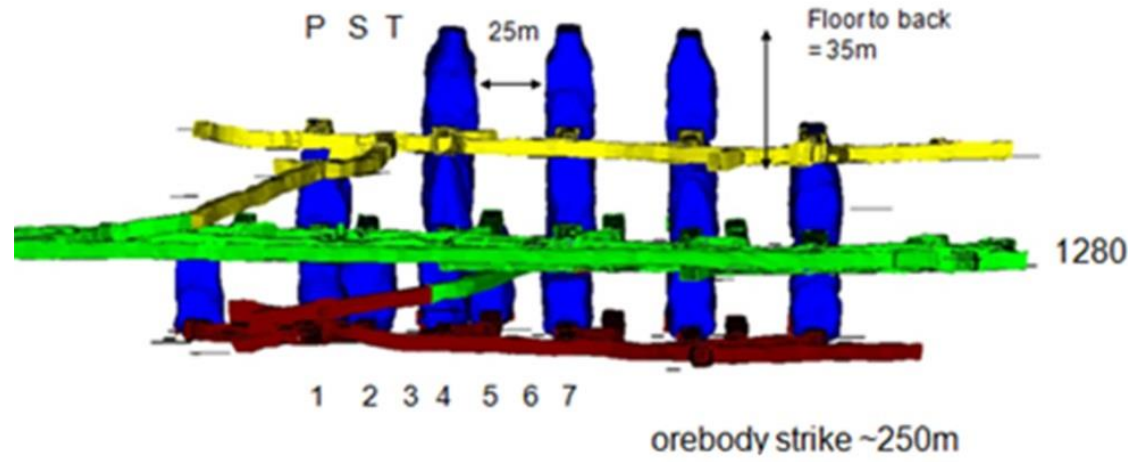

(b)

Figure 4 Contact zone stope layout (a); and the 1-4-7 sequence (b). The 1-4-7 refers to arbitrary crosscut line numbers and means the 1st, 4th, and 7 th crosscut lines can be mined independently and concurrently

\subsection{Footwall zone stope design}

The footwall (or copper) zone stopes was originally laid out as a primary/secondary 1-5-9 sequence, allowing every other primary stope to be mined concurrently (Figure 5). Strike length is $12.5 \mathrm{~m}$ and the number of panels in the transverse direction is determined by orebody thickness and stability graph design guidelines. The orebody is 1-4 panels wide in the transverse direction with typical panel length of 25-45 m. The last two sublevels approaching the sill pillars were switched to a restricted 1-3-5 sequence to avoid $3 \times 12.5 \mathrm{~m}$ squat pillar areas. Local empirical experience is that long/slender secondary pillars $(\mathrm{W} / \mathrm{H}<2 / 3)$ will yield without large magnitude seismicity. All secondary development is planned as just-in-time so that access tunnels are not subjected to excessive stress changes and are primarily developed in failed/stress shadowed ground. 


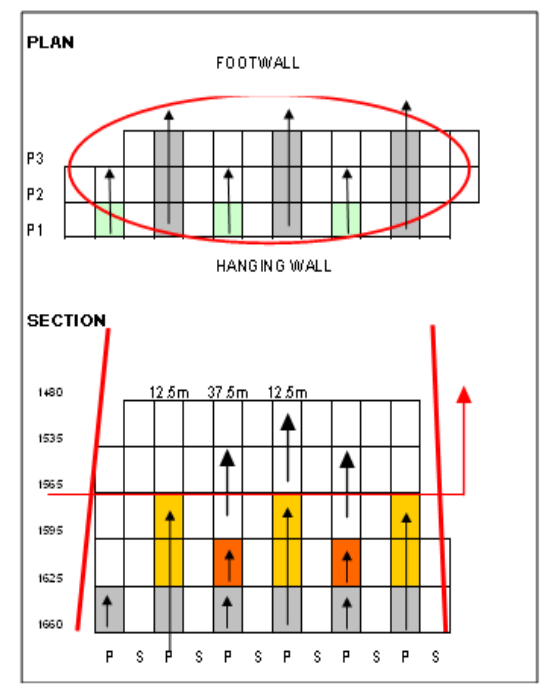

\section{$25,000-30,000$ t per panel}

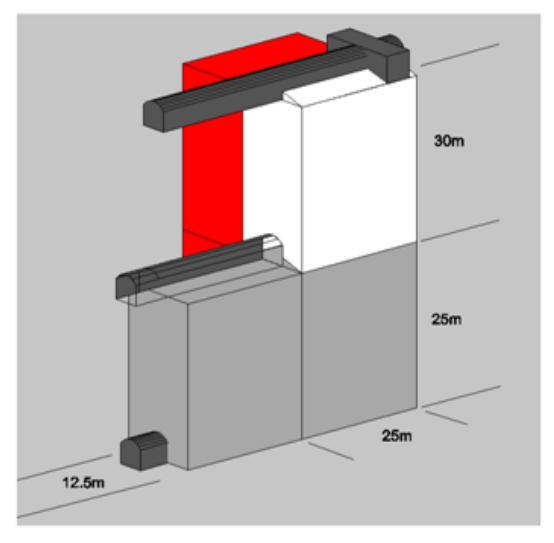

(a)
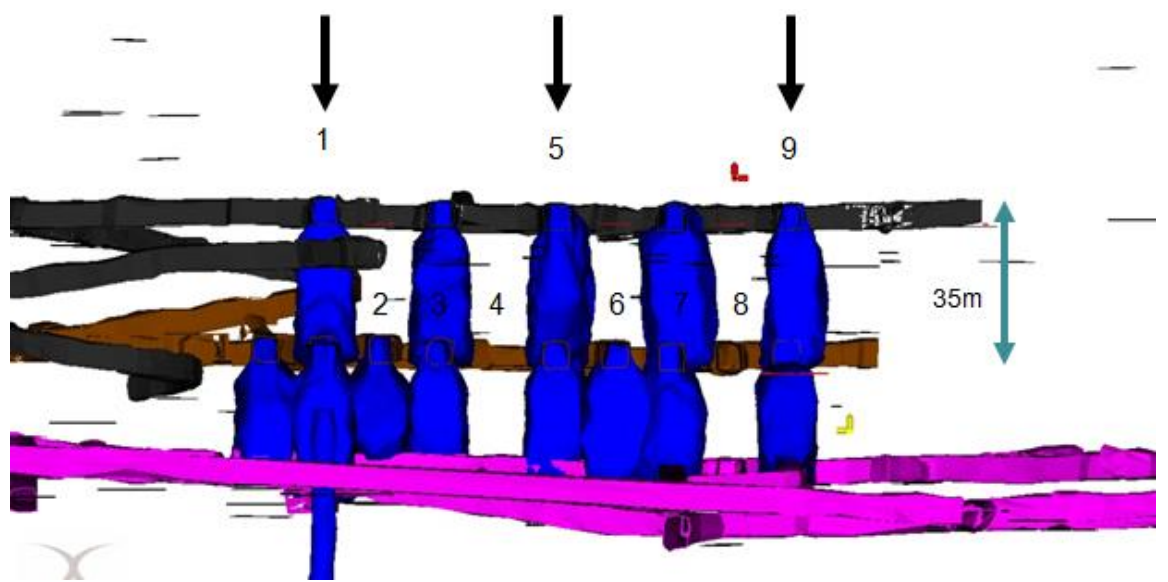

(b)

Figure 5 Footwall zone stope layout (a); and sequence (b)

\section{$4 \quad$ Seismic monitoring}

Nickel Rim South Mine is a relatively modern operation with stoping starting in mid 2009. A microseismic array was implemented in January 2009, five months prior to the first stope blast. The mine has a full fibre optic network underground, with a fibre hub at most electrical substations. The seismic array was relatively easy to implement because only short copper cable runs are required. The geometry of the orebody with both hanging wall and footwall access has also made it ideal for excellent seismic monitoring coverage. The resulting high resolution array has 51 sensors (79 channels) with an average spacing of $120 \mathrm{~m}$ (37 uniaxial accelometers and 14 triaxial geophones), given the relatively small overall mining volume $\left(<1 \mathrm{~km}^{3}\right)$ this provides dense coverage recording moment magnitudes below -2 . Small magnitude seismicity in itself rarely poses a safety risk, however, the cumulative effect of seismicity is an excellent record of rock mass damage. This has proven to be a very useful tool for numerical modelling calibration, and general rock mechanics understanding (Beck et al. 2012; Simser 2013). Several examples are included in the following sections to show how the high resolution data is used to track overall rock mass response to mining (Figure 3). 


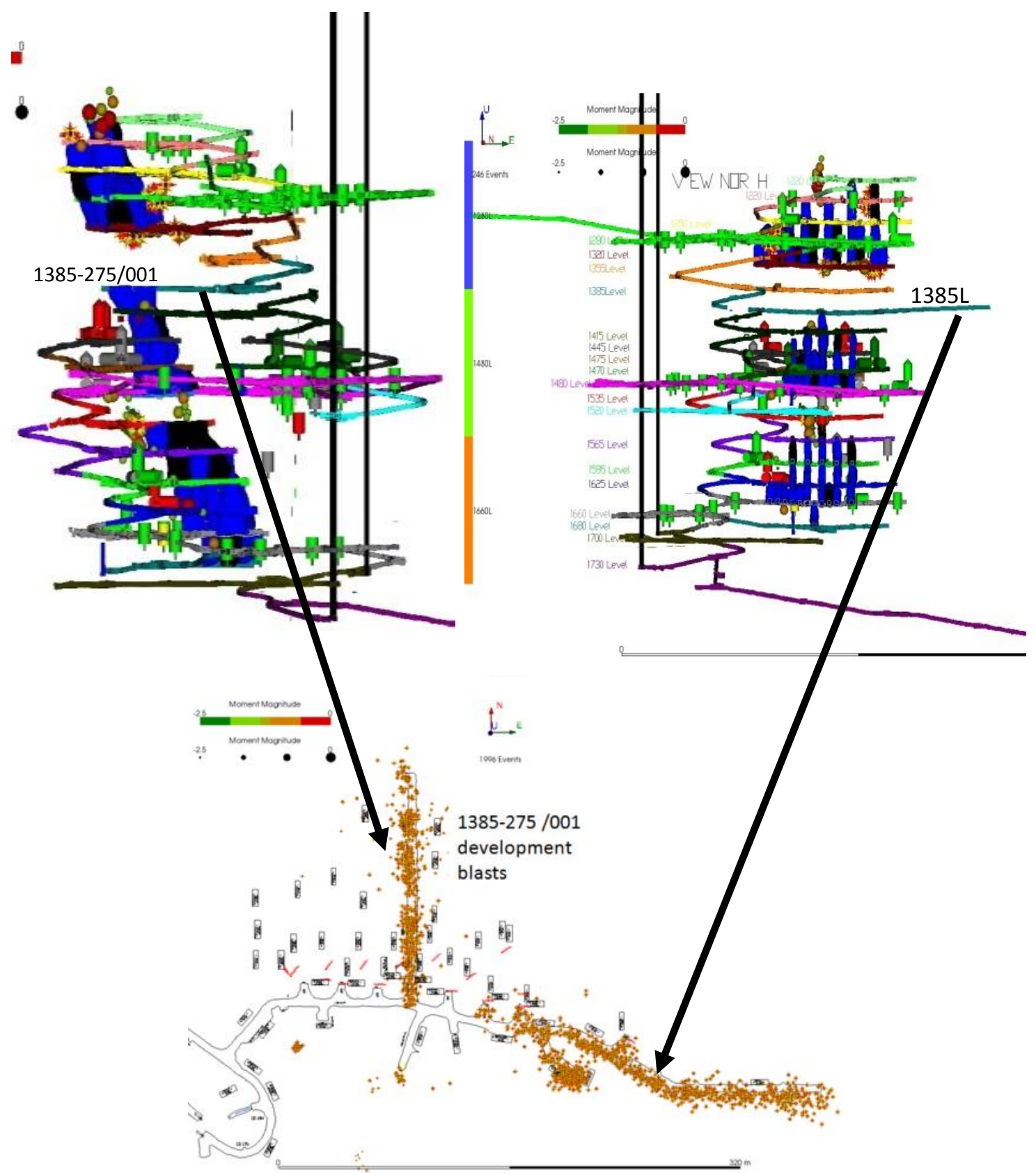

Figure 6 Top left picture is a cross-section of mine with cylinders depicting seismic sensor locations (both in the hanging wall and footwall of the orebody). Top right picture is a long-section view of the sensor locations, the abundance of sensors near the shaft access (west abutment of orebody) was an artefact of getting the array in as early as practical. The bottom picture shows development blasts as located by the seismic array on the $1385 \mathrm{~L}$ tracking the mine survey data which implies about $5 \mathrm{~m}$ location accuracy

Seismic array accuracy and sensitivity will vary over the different areas in the mine, especially given the constant velocity model used for source locations. In the best portions of the array $5 \mathrm{~m}$ location accuracy is usually obtained, and in the fringe areas accuracy can drop off to $+/-20 \mathrm{~m}$. The more accurate data can be used to answer relatively precise rock mechanics questions. For example, the primary/secondary stoping layout has $12.5 \mathrm{~m}$ wide pillars. Accurate data can be used to infer the stress state on the stope scale. 


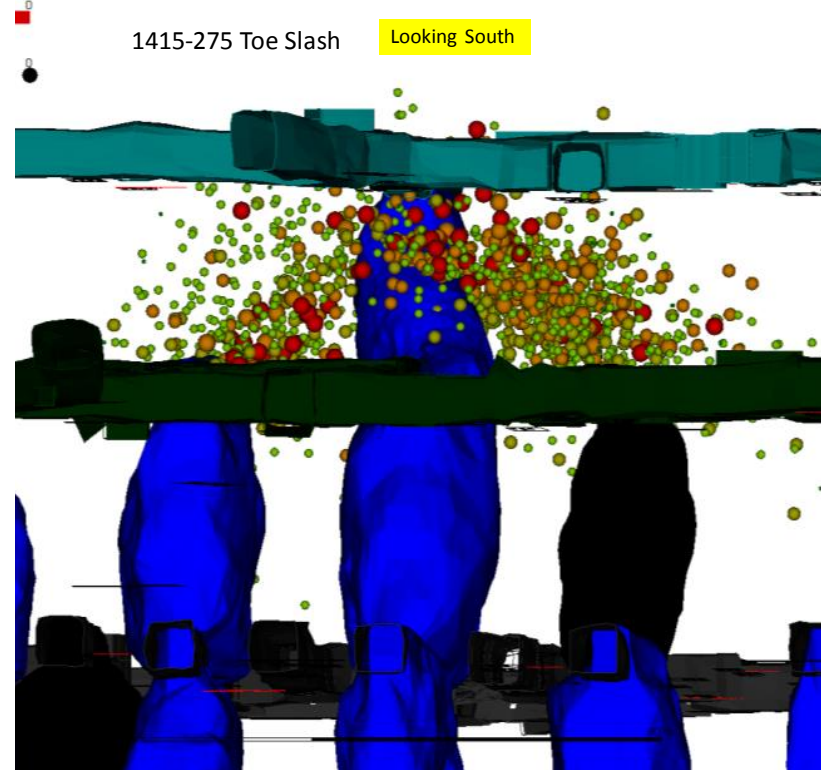

(a)

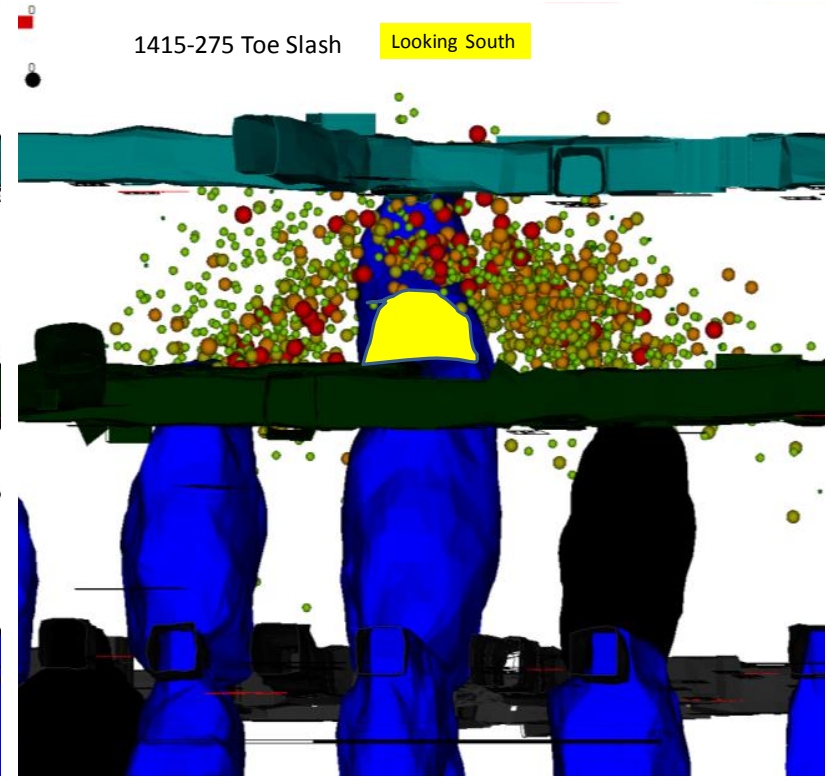

(b)

Figure 7 (a) seismic response to the first panel blast (bottom $1 / 3$ of $30 \mathrm{~m}$ long $125 \mathrm{~mm}$ blastholes fired around a $1.2 \mathrm{~m}$ diameter raisebore); (b) area highlighted in yellow corresponds to the exact blasted area (i.e. almost no seismicity mislocated in the newly formed void). The panel strike length is $12.5 \mathrm{~m}$ (left to right in the figure). Note minimal seismicity in the lower secondaries because they had already yielded

The seismicity shown in Figure 7 is also a record of the abutments to the stope yielding. These areas eventually become secondary stopes which are mined after two lifts of primaries on both sides have been extracted. By the time the secondary stoping line (or pillar) is mined, the local rock mass has yielded and emits no further seismicity except for recorded blasts.

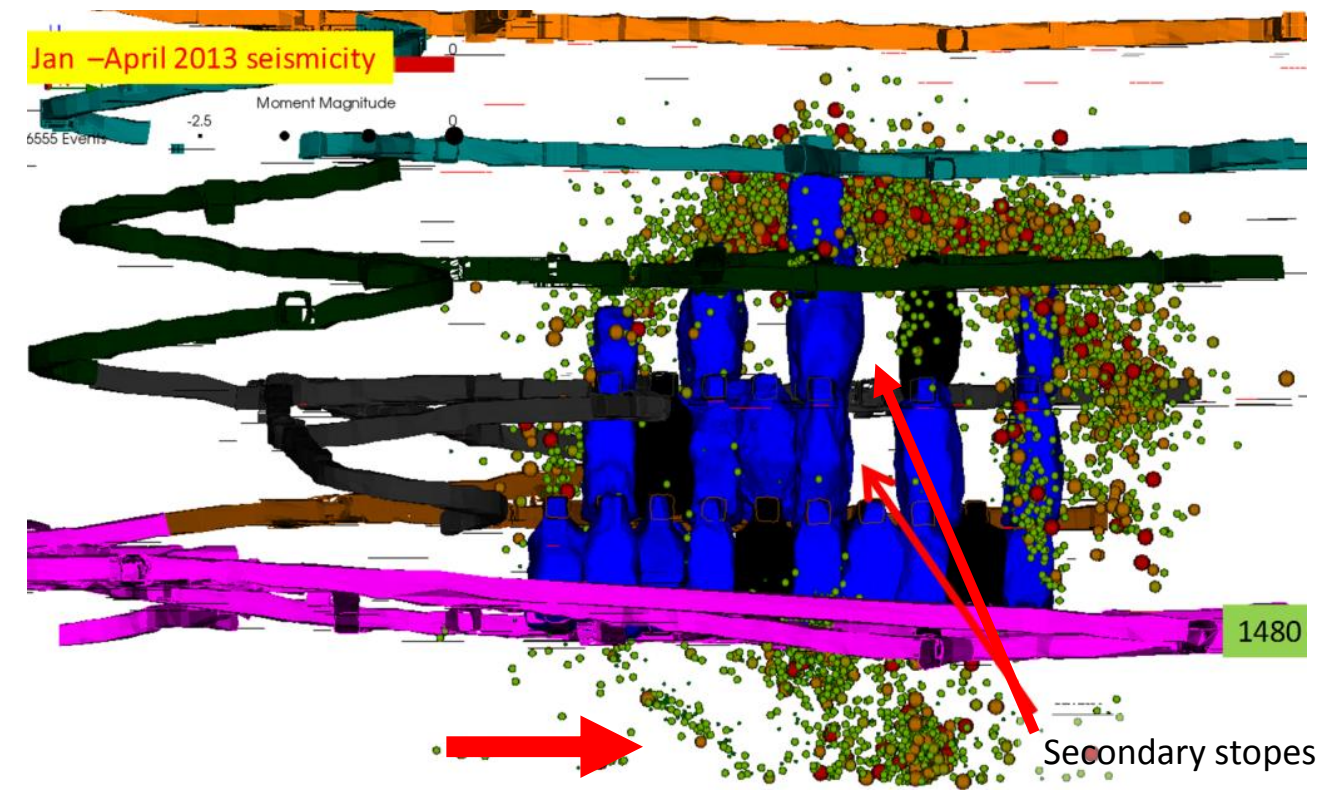

Figure 8 Over time the secondary stopes show up as seismic gaps (shown by thin arrow). The activity in these volumes of rock is associated with primary stope mining on either side (Figure 7) but after the secondary is fully formed, no more seismicity is recorded, even at the moment magnitude -2 level (indicative of rock mass yielding). The wider arrow highlights seismicity following a 
mapped fault plane. Development blasting is routinely recorded when the justin-time crosscuts are driven into the secondaries. The waveforms show a characteristic high frequency attenuation which is fur ther evidence of cracked ground

\subsection{Just-in-time development}

It is critical for the type of the layout shown in Figure 8 not to develop tunnels into the secondary pillar until it has yielded (just-in-time development). The yielding process would badly damage the crosscut, and more importantly, on the scale of $12.5 \mathrm{~m}$ stopes, the primary stope blastholes would be too close to the secondary access and likely punch through into the crosscut. The preferred panel firing sequence is to take the stope in two blasts, the first as per Figure 7 to establish void, and then a final shot (larger stopes may require three blasts). This reduces worker exposure and having to deal with redrills caused by holes plugging/squeezing. A $12.5 \mathrm{~m}$ wide secondary would by design only have a $3.5-3.75 \mathrm{~m}$ rib between the $5 \mathrm{~m}$ wide crosscut and the filled primary stope. In the yielded state this equates to a lower quality rock mass and gravity loading only. Seismicity is reduced to far field event shake damage, with no local strain energy coming into effect.

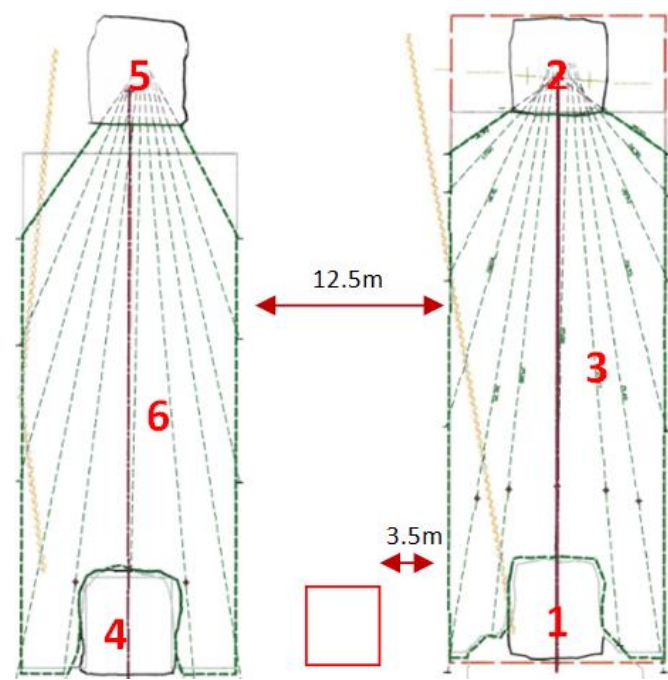

Figure 9 Blasthole drilling layout. Note the proximity of the secondary access to the primary stope blastholes. The secondary accesses are only driven after the primary stopes are mined and filled

\section{$5 \quad$ Rock mechanics challenges}

\section{$5.1 \quad$ Sill pillars}

Sill pillars or converging mining fronts are often a necessary mine design decision to ensure independent mining fronts and the early ramp up of production. In the longer term, the resulting sill pillar area can be difficult to extract with increased seismicity and the risk of rockbursting. The two planned sill pillars at Nickel Rim South have been a main focus of the ground control program since mining started. The extraction strategy is essentially a centre out chevron front, with early breaching of the lower sill pillar. The upper sill is offset in time to delay having two main production horizons in an elevated stress state (Figure 10). 

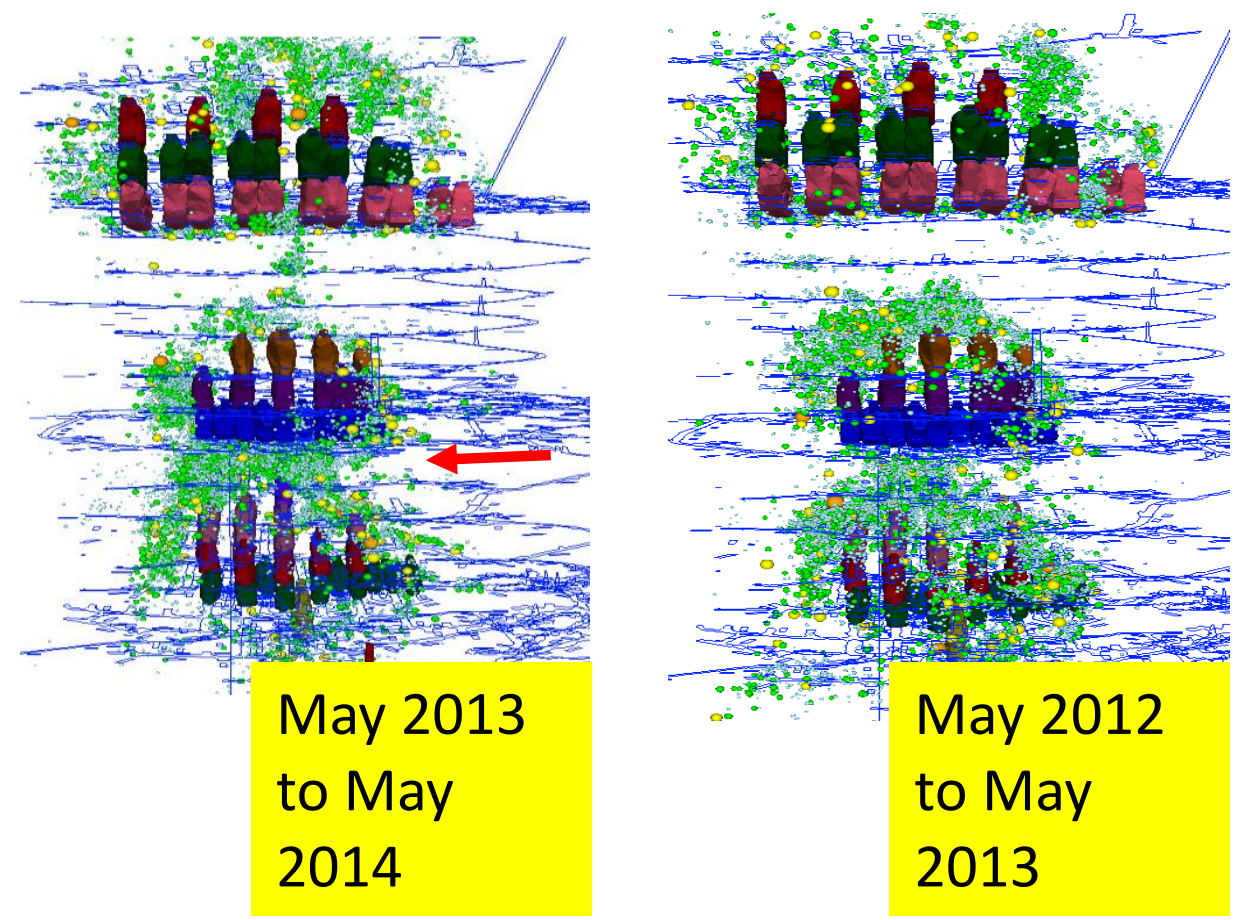

(a)

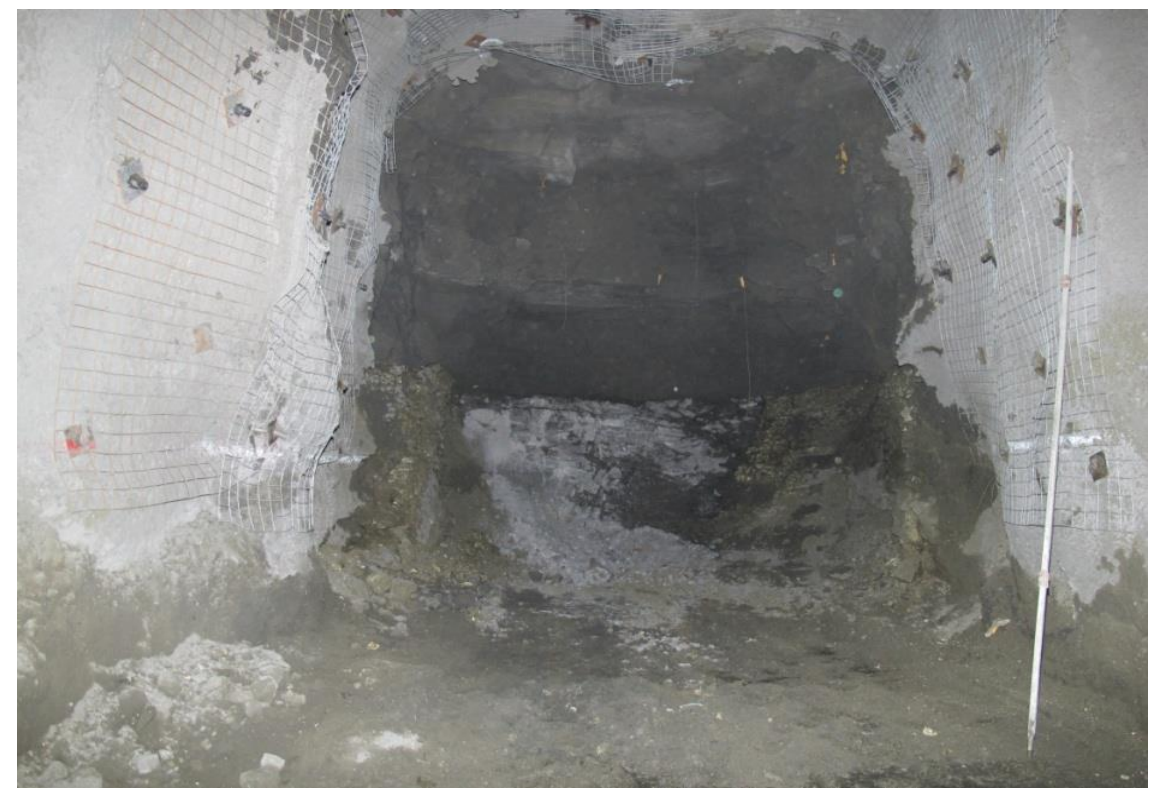

(b)

Figure $10 \quad$ (a) yearly seismicity around the stoping areas showing the lower sill area (shown by arrow) with elevated microseismicity and the upper sill area having little interaction between the two mining blocks at this stage of the extraction sequence; (b) development under backfill - stope overcuts under the sill elevation backfill are used to create a safe drilling area. The backfill does not store significant strain energy (will not burst) and the lower portion in rock is stress fractured from the stoping (also will not store significant strain energy)

The stoping strategy in the last tier of mining (the sill pillar) is to mine under backfill to create an overcut in a stress shadowed state. The first tier stopes were filled using cemented tailings with $8 \%$ binder in the first $7 \mathrm{~m}$ and $5 \%$ for the remaining stope pour. The overcut is driven using in-cycle shotcrete, mesh and swellex 
style bolting. The undercut area is still in an elevated stress state, enhanced ground support is used while developing and then remote control equipment for mucking.

\subsection{Geology (complex fault system)}

There are numerous examples of asymmetric seismicity or, in the case of Figure 11, abnormally high seismicity that can only be explained when considering the faulting. The fault slip risk is similar to most mines, in that it is both a function of overall driving stresses (increasing with overall extraction) and fault mobility. Fault mobility increases as more stopes pierce the structure, and/or de-clamp portions of it. For reasonably accurate long term forecasting of mine behaviour, these structures must be taken into account (see Section 6).

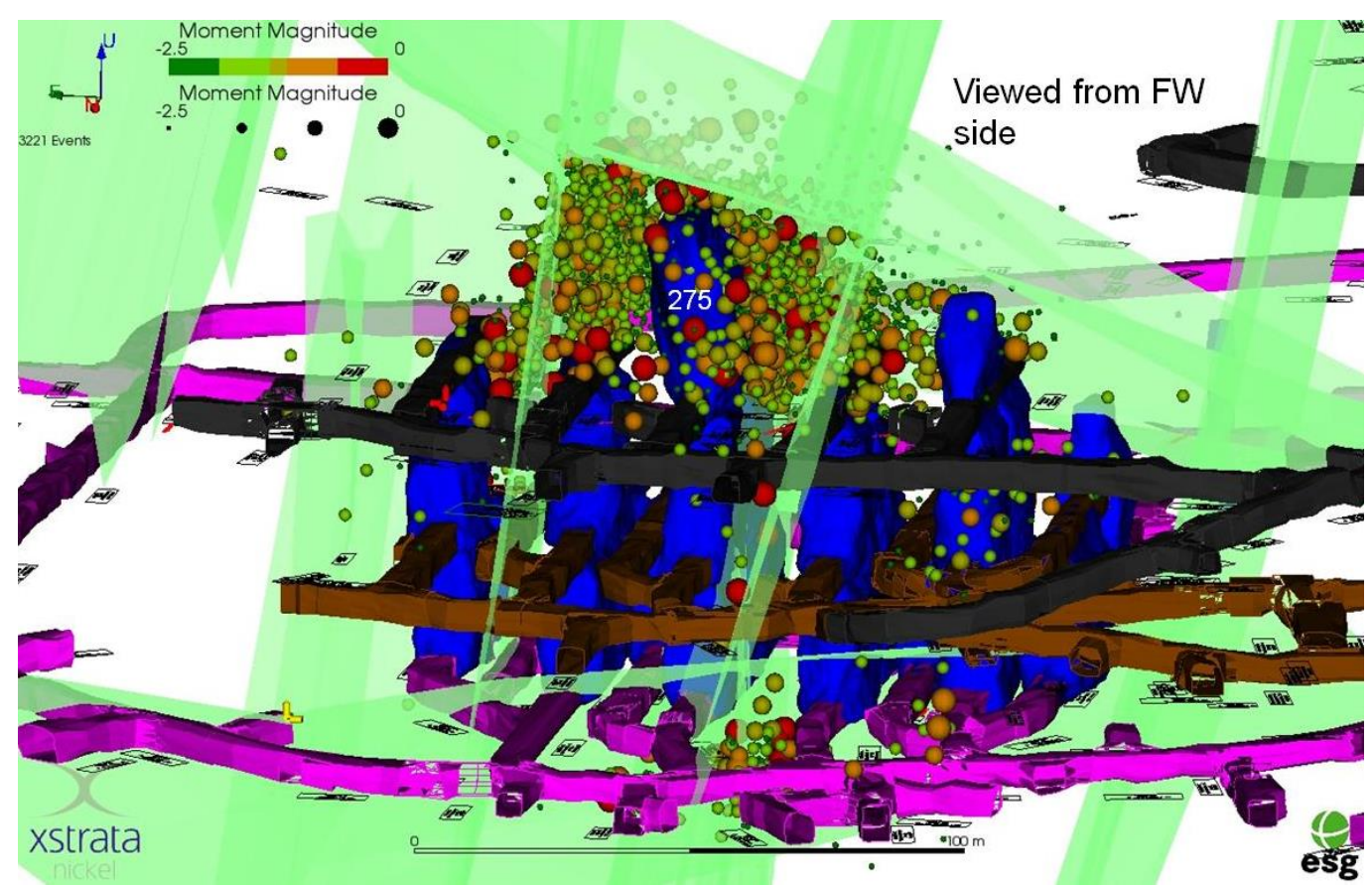

Figure 11 Seismic response from a copper zone primary stope surrounded by faults. This stope was mined in autumn of 2011 and to date has generated the highest event rate at NRS from a single stope (based on 24 hour response). The faulting creates an effective stress barrier, channelling higher loads bet ween the structure and the void

\subsection{Narrow rib pillars (rockbursting) and ground support strategy}

An artefact of narrow transverse stoping layouts is the creation of relatively thin rib pillars in the draw points. During the primary mining, the pillar between stope accesses is nominally $20 \mathrm{~m}$ for the 12.5 strike length stopes. Once the secondary access is driven, this pillar is bisected. With $5 \mathrm{~m}$ wide accesses the pillar becomes $2 \times 7.5 \mathrm{~m}$ ribs. On the sill elevation where horizontal stresses wrap around the mining front, near vertical loading conditions persist. The rib pillar has an effective width to height ratio of 5:7.5 which is a relatively squat pillar that can store energy. Figure 12 shows an example of this type of pillar bursting.

The mine started off as an in-cycle shotcrete operation with $50 \mathrm{~mm}$ of fibrecrete and $22 \mathrm{~mm}$ rebar as primary support. In burst-prone areas, mesh is now systematically applied over the shotcrete, and in some cases the rebar changed to yielding type bolts. Some attempts were made to destress the ribs as they were formed, but more work is required to ensure the explosives used don't just rifle out the collar of the destress hole. Currently a strategy of restricted access and enhanced ground support is being used. 


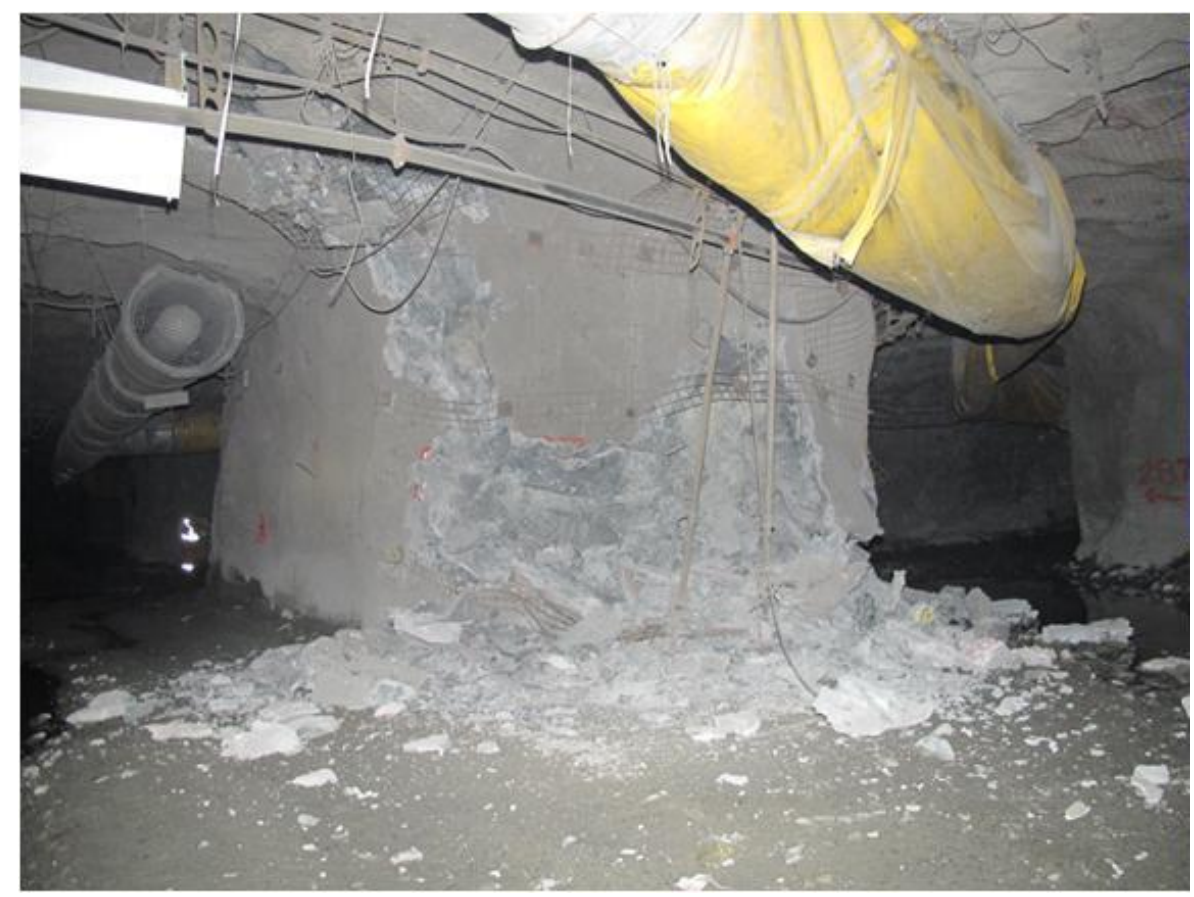

(a)

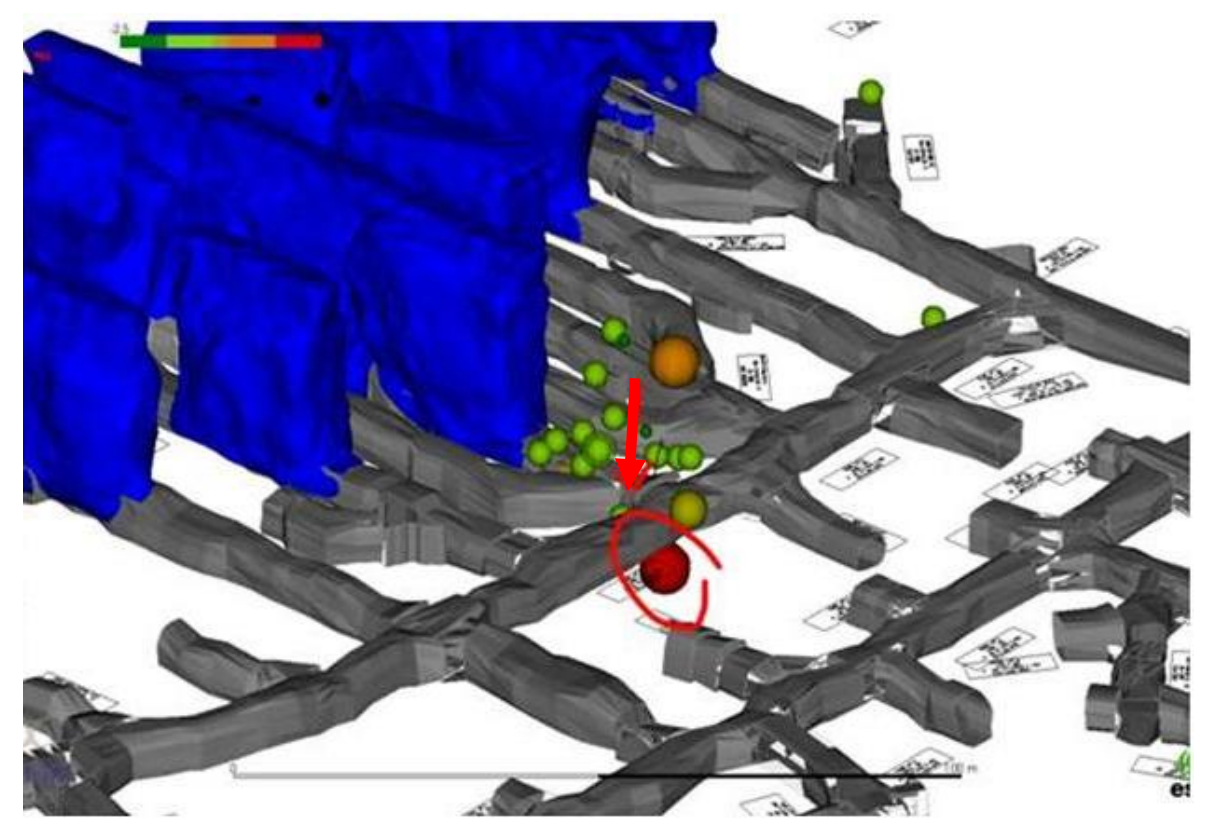

(b)

Figure 12 (a) rockburst after a moment magnitude 1.3 seismic event; (b) red (circled) ball showing event location and an arrow showing the narrow rib pillar

\subsection{Evolution of ground support practice}

Shotcrete performance at Nickel Rim South generally has been very good. However shotcrete is a fundamentally brittle material that cannot sustain high deformation. The overall rock mass quality is good to very good, so the initial in-cycle shotcrete reinforces natural weaknesses in the rock mass (joint planes, as well as stress and blast induced fractures). During the development phase and even some of the stoping induced changes (both stress and blast vibration) the overall deformation around the drives is typically only a few centimetres, still within the bandwidth of high quality fibrecrete. However when higher stresses such 
as sill pillar areas, and/or repeated loading from nearby stopes is taken into account, the deformation around the skin of the stope accesses can exceed the capacity of fibrecrete (Figures 12 and 13).

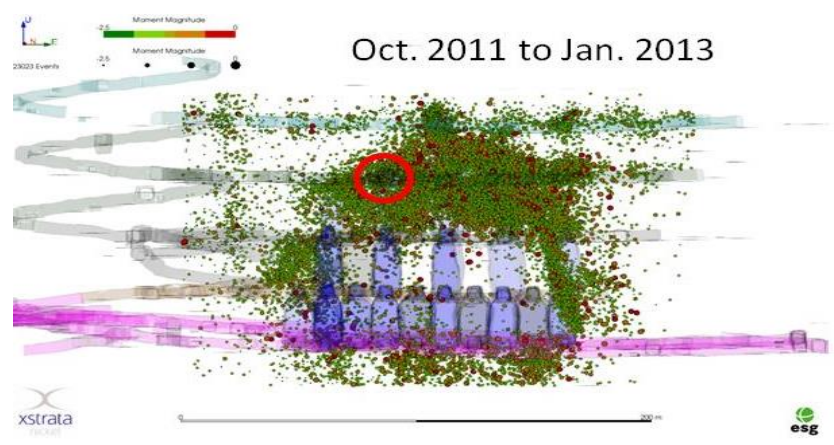

1. Fracture zone develops around stope crosscut

2. Mine stope below

3. blast stope $12.5 \mathrm{~m}$ away
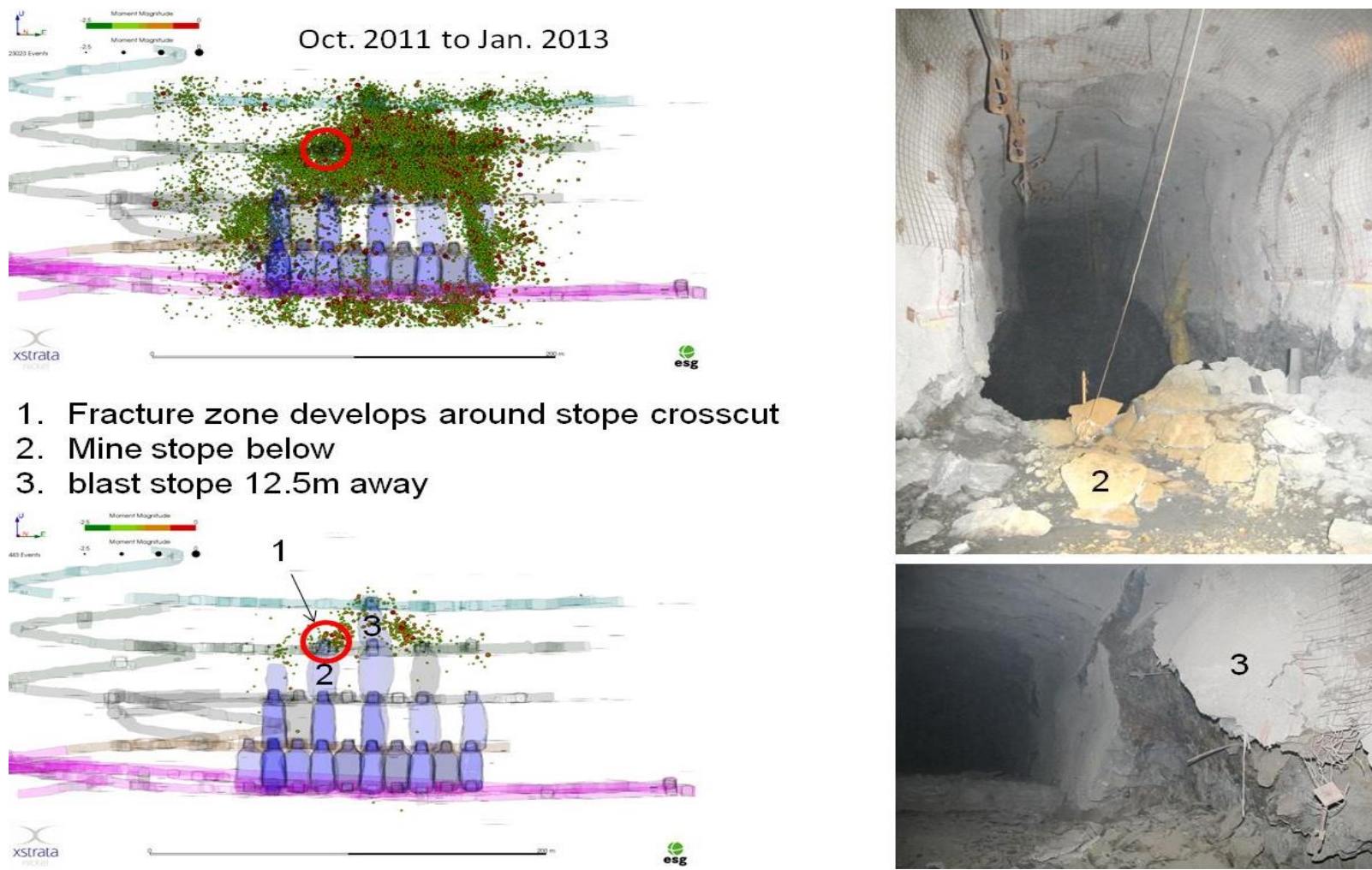

Figure 13 Top left - 23,000 microseismic events over a 15 month period (scale bar is $200 \mathrm{~m}$, long section view). Bottom left seismic response after final blast in stope 3. Top right - crosscut 1 still in reasonable condition after stope 2 mined. Bottom right - fatigue, blast vibration from stope 3 dislodged the fractured wall on top of stope 2 backfill. Photos are both in crosscut 1 , numbers refer to mining step

The evolution of damage over time is shown in Figure 13. Depending on the local mine layout, this type of damage can be managed with non-entry and/or enhanced ground support. For narrower portions of the orebody, when the previous tier's overcut becomes the next tier's undercut, there may not be any personnel-entry requirements. A remote procedure is used to attach the raisebore reamer bit for the slot drilling, all other blastholes are drilled top down, and remote mucking can be used. In wider portions of the orebody where multiple panels per crosscut line are required, enhanced support is used.

Enhanced support is primary weld mesh over shotcrete, the shotcrete still keeps key blocks in place and limits overall rock mass dilation. The mesh takes over if/when deformation limits for shotcrete are exceeded. Other enhancements may include double plating of the rebar $(300 \times 300 \mathrm{~mm}$ mesh strap plate covered by $125 \times 125 \mathrm{~mm}$ steel plate), $4.6 \mathrm{~m}$ twin cable bolts, in some cases $3.5 \mathrm{~m}$ super swellex bolts, and ' $D$ ' bolts replacing rebar (higher deformation steel stretch bolts). Incremental improvements are ongoing, for example a switch to $5.7 \mathrm{~mm}$ diameter weld mesh versus $4.9 \mathrm{~mm}$ (\#4 gauge from \#6 gauge) is being trialled with denser bolting $(0.9 \mathrm{~m}$ spacing versus $1.1 \mathrm{~m})$ instead of the shotcrete/mesh combination. These types of changes often take a few years to fully appreciate the cost benefits. For example in Figure 13, the original crosscut was driven in 2012 and the adjacent stope was mined approximately 15 months later. The blast vibrations from the adjacent stope are analogous to a series of large magnitude events occurring nearby. The seismic system measures the shots as moment magnitude $\sim 1.0$ for the initial blast timing around the raise and about magnitude 1.5 for the slash holes afterwards. With the $12.5 \mathrm{~m}$ stope spacing, the adjacent primary crosscut can see several episodes of high blast vibration (albeit at higher frequency than seismic events so not directly comparable). 


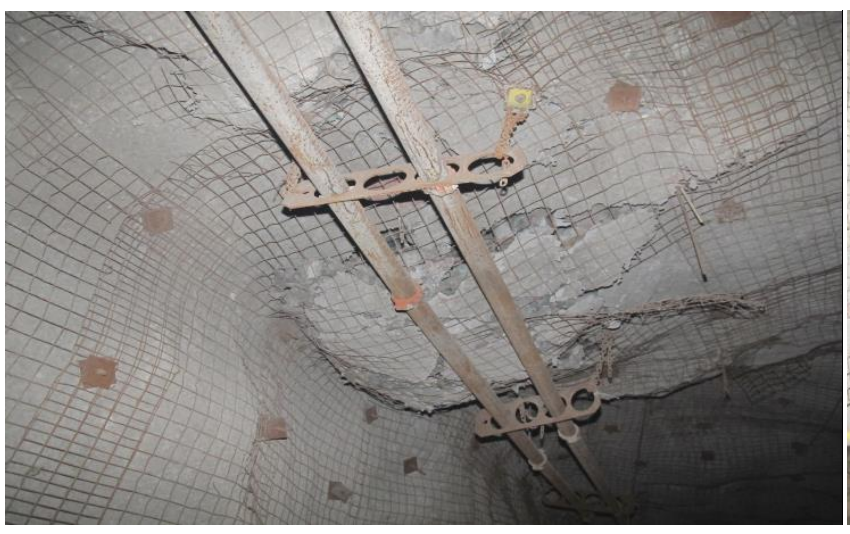

(a)

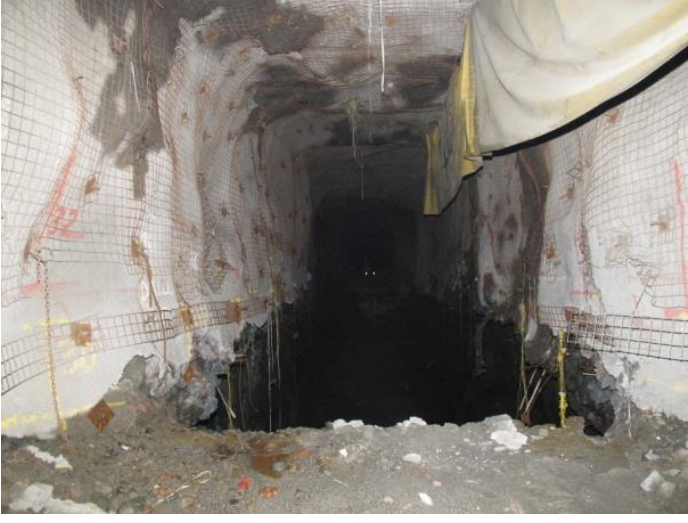

(b)

Figure 14 (a) mesh over shotcrete containing rockburst damage; (b) enhanced support holding after stope in sill pillar region mined

\section{Tools to tackle the rock mechanics challenges}

\subsection{Mine design}

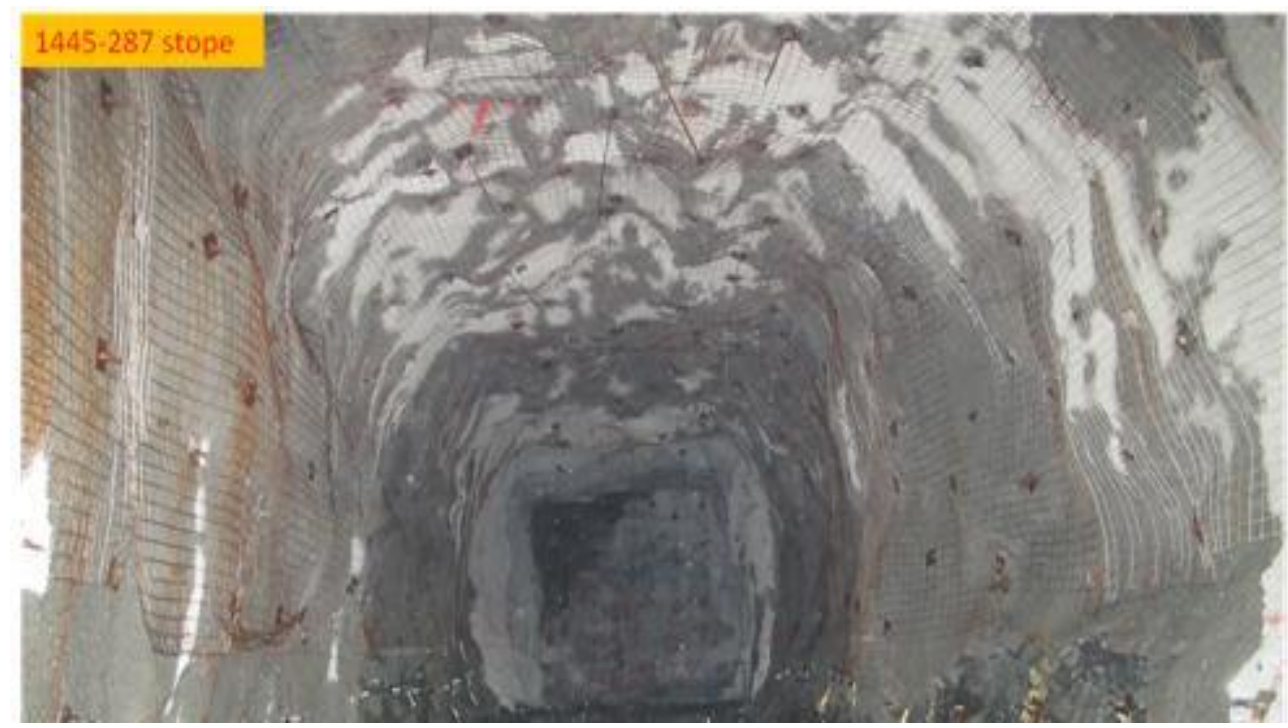

Figure 15 Photo of secondary stope access. The water inflow is from hydraulic backfill vertically above. The water makes its way through the fractured ground and/or mine wide faults. This is an indication of rock mass failure, primary stopes have no process or ground water inflow unless they intersect an ungrouted diamond drill hole

The primary/secondary stoping method has evolved from shallower mining layouts which used the sequence to create independent mining fronts for productivity reasons. In the deep mine context, allowing approximately half of the stopes to yield out and not store local strain energy is a good way to manage rockbursting. It is important to ensure the pillars are slender enough so they do not fail too violently. The rule of thumb used at NRS is to keep the width/height ratio less than $2 / 3$. This has been verified by numerical modelling, seismic monitoring and field observations which shows the secondaries are yielded, and didn't yield with excessive magnitude seismicity.

The yielded blocks of ground change from a potential rockburst risk to a deadweight and fall of ground risk. Generally this is easier to manage with respect to ground support design and monitoring capabilities. The gravity risk increases as mining progresses. For example a second tier secondary stope will have a backfill foundation. Multiple panel crosscuts develop into secondary stopes surrounded by cemented backfill on all 
sides except the footwall. The diving board must have a foundation to transfer some of the load. The thin ribs between the stope crosscut and the primary panel need to stay relatively intact to transfer some of the dead weight. The retaining wall effect of the backfill on the stope walls also accounts for some of the load carrying capacity. In some cases topping up the backfill into the overcut is required. This has to be removed or re-developed over top when the next tier mining utilises the excavation as a mucking horizon (undercut). The overall mine design - particularly stope sequencing remains the most important consideration for safe mining in the deep context. A centre out overall sequence is used, the lower reserves are mined top down under the first levels' backfill (1,660 m below surface) to avoid creating another sill pillar. Narrow ends of the orebody are planned as an end slicing, pillarless sequence (avoiding squat secondary pillars).

\subsection{Geohazmap (forecasting strainburst hazard)}

Three fundamentally different risk forecasting tools are being used to varying degrees at Nickel Rim South: geohazmap; non-linear numerical modelling; and mXrap (Australian Centre for Geomechanics 2014) advanced seismic analysis. The geohazmap tool was developed in conjunction with Centre for Excellence in Mining Innovation (CEMI), Mira Geoscience (McGaughey 2014), and several Sudbury Mines including Glencore's historic Craig Mine. The risk forecasting approach is important for the operation to prioritise ground support upgrades, implement seismic re-entry protocols by pre-defining potential areas impacted by a specific stope blast, and for more reliable operations planning. The geohazmap approach involves building a sophisticated block model of the mine including: geological information (lithology, structure); geotechnical variables such as RQD, core disking; microseismic data including source parameter information; numerical modelling results or extraction ratio proxies for stress increase; and whatever other types of spatial information that is deemed important (ground support, ground water, etc.). A positive spin-off of the approach is being able to block model geotechnical data rather than using our historic approach of linking geotechnical data to 3D diamond drill hole data (Figure 16(a)).

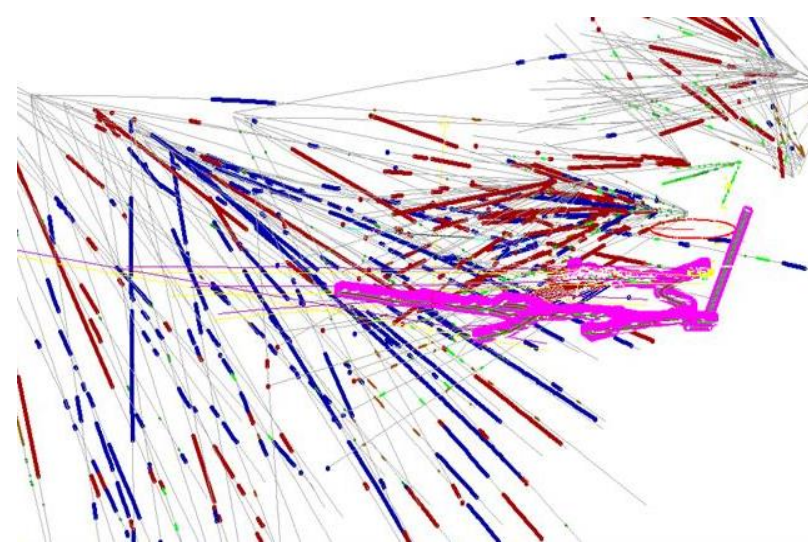

(a)

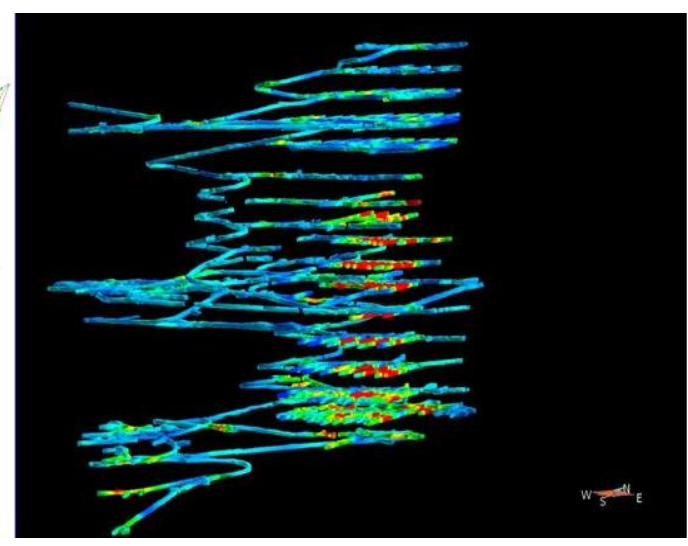

(b)

Figure 16 Left core disking in red and high fracture frequency in blue from Craig Mine historic data. Right - core disking contoured onto mine surfaces for Nickel Rim South Mine. The core disking areas at NRS are usually associated with weak copper veins rather than abnormally high stress. In the Craig Mine case, the disking occurred in very strong granitic rock was indicative of high stress anomalies

The general objective of Geohazmap Workflow is to quantitatively forecast geotechnical hazard within a mine by combining a set of spatially modelled, normalised, and weighted hazard criteria. Different hazards can be assessed, but in the Nickel Rim South case, strain and rockburst case histories were used as training data (for an expert system approach). The different parameters built into the spatial model such as distance to faulting can be assessed in a statistical and objective manner to determine their relative importance with respect to the hazard.

Hazard $=f$ (geology, stress, geometry, rock quality, microseismicity, other variables). 
Table 2 Example results from the geohazmap analysis

\begin{tabular}{|c|c|c|c|c|c|c|}
\hline Criteria & $\mathbf{W +}$ & W- & Contrast & $\begin{array}{l}\text { Studentised } \\
\text { contrast }\end{array}$ & $\begin{array}{c}\% \\
\text { FOG }\end{array}$ & Note \\
\hline $\begin{array}{l}\text { Proximity to } \\
\text { dykes }\end{array}$ & 0.85489 & -1.15636 & 2.01125 & 535.4 & 79.1 & Within $30 \mathrm{~m}$ of a dyke \\
\hline $\begin{array}{l}\text { Event (seismic) } \\
\text { density }\end{array}$ & 0.75657 & -0.76366 & 1.52023 & 64.2 & 68.3 & $\begin{array}{c}\text { Near microseismic data } \\
\text { cluster (previous } 6 \text { months) }\end{array}$ \\
\hline Depth & 0.79944 & -0.66653 & 1.46597 & 46.2 & 63.3 & Deeper than 1521 \\
\hline $\begin{array}{l}\text { Pre-mining } \\
\text { disking }\end{array}$ & 0.69557 & -0.52238 & 1.21795 & 39.3 & 57.8 & Near disking \\
\hline $\begin{array}{l}\text { Pre-mining rock } \\
\text { quality }\end{array}$ & 0.52122 & -0.90029 & 1.42151 & 38.3 & 78.2 & RQD lower than 39.9 \\
\hline Lithology & 0.66358 & -0.52662 & 1.19021 & 38.2 & & Within LGBX \\
\hline Intersection & 0.49116 & -0.58561 & 1.07677 & 33.0 & 67.2 & $\begin{array}{l}\text { Within } 12 \text { m of a drift } \\
\text { intersection }\end{array}$ \\
\hline $\begin{array}{l}\text { Proximity to } \\
\text { fault }\end{array}$ & 0.15915 & -1.82243 & 1.98158 & 21.2 & 97.2 & Within $37 \mathrm{~m}$ of a fault \\
\hline $\begin{array}{c}\text { Microseismic } \\
\text { source } \\
\text { proprieties }\end{array}$ & 0.72863 & -0.09895 & 0.82757 & 20.1 & 16.7 & $\begin{array}{l}\text { Near microseismic data } \\
\text { with relatively high Es/Ep }\end{array}$ \\
\hline
\end{tabular}

A hazard rating system can then be determined and the mine excavations contoured accordingly. This provides useful guidance for support planning purposes, for example where to install mesh over the original fibrecrete and rebar support system.

The hazard score as shown for rockbursts is a combination of the following criteria, in decreasing order of importance, appropriately weighted and summed as determined by the statistical analysis (depth, proximity to dykes, proximity to pre-mining disking as indicated from the geotechnical drill hole database, low RQD, microseismic event density over previous six month window, proximity to drift intersections, locally high Es/Ep in microseismic data, within LGBX rock type, proximity to faulting).
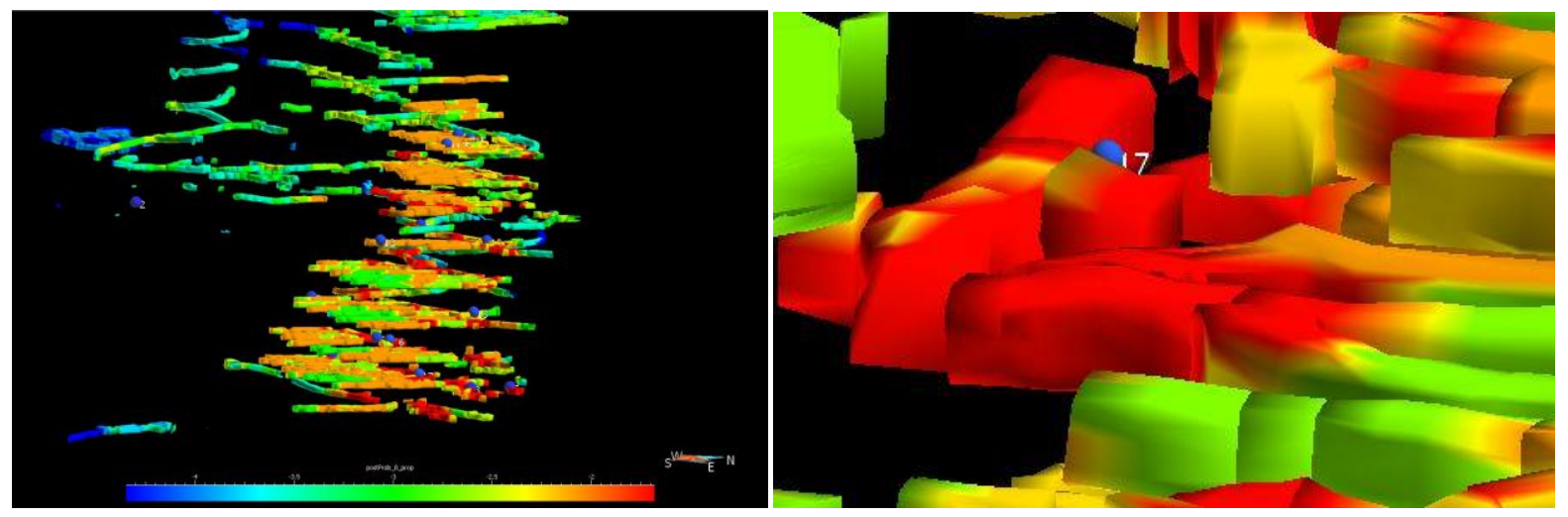

Figure 17 Lower mine development with interpolated colour hazard rating. Blue spheres indicate historic strainburst locations or training points for the model. Right - close up a high risk area

The training data used largely consisted of relatively small strainbursts (18 data points). As mining progresses more data can be used to help improve the calibration of the model. 


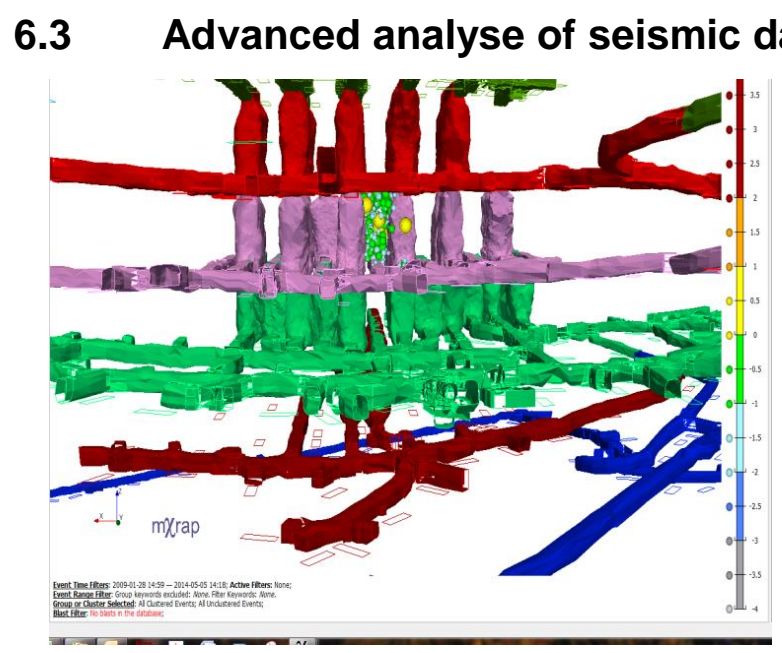

\section{data (mXrap)}

\section{Figure 18 Example of data analysis from $m$ Xrap (Australian Centre for Geomechanics 2014)}

The mXrap software suite developed by the Australian Centre for Geomechanics allows for rapid assessment of seismic source parameter information as well as seismic hazard assessment (Hudyma 2005). The example from Figure 18 follows mine seismology principles developed in the early 1990s (van Aswegen \& Butler 1993; Mendecki 1993). The 2014 twist is simple: high resolution seismic data. The left hand figure shows a cluster of seismicity in a $12.5 \mathrm{~m}$ wide secondary pillar. This implies accurate seismic locations, or the analysis could be mixing mechanisms for example failing rock in the pillar versus high stress abutment loading only a few metres away. The right hand side of the figure is a stress strain analogy. The green plot is cumulative apparent volume where the slope is indicative of seismic strain rate. The steep jumps in the plot correspond to the primary stope mining before the secondary pillar is fully formed (high strain rate). The flat plateau at the end of the plot corresponds to no seismicity, when the pillar has failed. The blue curve is an energy index plot, the inference is high stress areas are clamped and do not facilitate high deformation. This translates to relatively high seismic energy (high stress) and low seismic moment (low deformation). Although the parameter can be spiky in nature, it is clear that an overall load shedding trend exists corresponding to the pillar failing.

A great deal more functionality exists within the mXrap software, and work is ongoing with collaborative research. However it is clear that some of the existing mine seismology principals can be revisited with the high spatial resolution data.

\subsection{Modelling}

Some in house numerical modelling is routinely done with 3D boundary element elastic tools and 2D non-linear codes. However the mine has relatively complex geology, especially the faulting and is contained within a relatively compact volume (roughly $375 \mathrm{~m}$ strike, $350 \mathrm{~m}$ dip direction, $585 \mathrm{~m}$ vertical). Significant volumetric rock mass fracturing (inelastic deformation) and mining front interaction have occurred relatively early in the overall sequence. 3D non-linear models are out sourced to Beck Engineering who provides some interpretation of the results as well as the results files for local mine site engineers to assess. The main calibration tool has been clustered seismicity which is related to commutative plastic strain in the model (Beck et al. 2012). The output is used in short term and long-term planning, prioritising enhanced support installation, location of non-entry zones after stope blasting, and to focus efforts where alternate sequencing may alleviate some potential ground control problems. To date, there has been good correlation with model forecasts and observed seismicity/damage underground. 


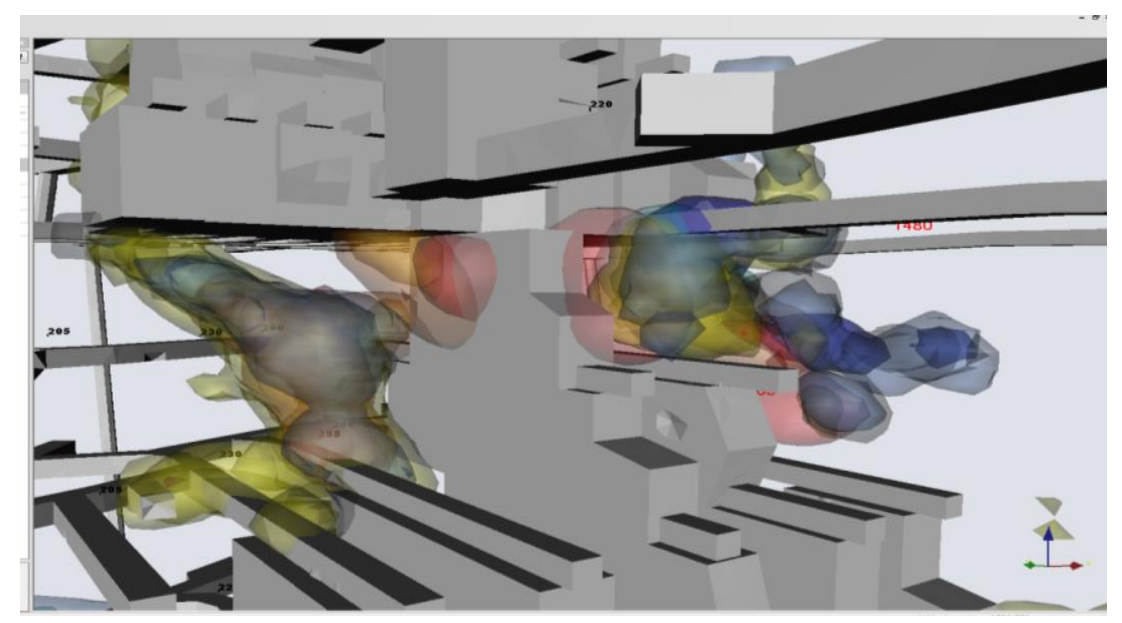

(a)

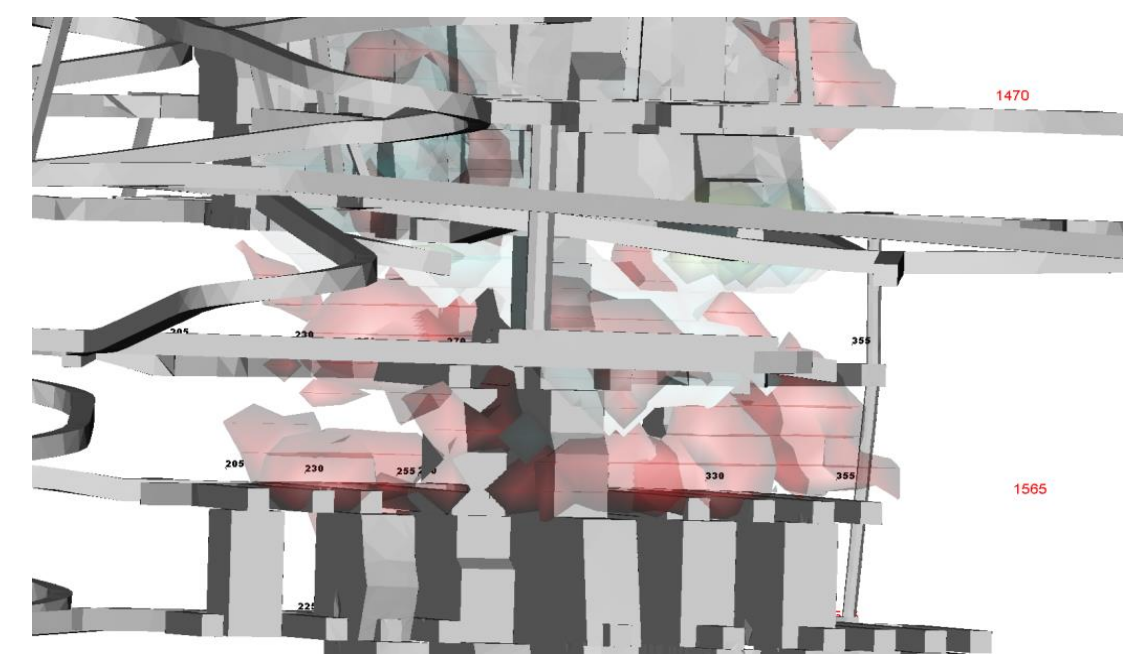

(b)

Figure 19 (a) contours of clustered seismicity after stope blast; (b) model forecast prior to blasting the same stope. The contours represent expected high energy release

The models take into account fault deformation as well as rock mass fracturing/dilation. Future work will look at some physical deformation monitoring to help fine tune the calibration process. To date, the high energy release has corresponded well with clustered seismicity after blasting. More work is required to quantify the potential magnitude range of the release, however high event rates tend to have higher probability of large events (power law relationship or so-called Gutenberg-Richter relation).

The modelled fault interaction from mining implies relatively far field affects. For example the modelled step in Figure 20 has a stope extracted from the lower mining block and reaction in the upper mining block. This follows observed seismicity where occasionally rogue type events (real events with accurate location) appear in a mining block that can't be accounted for by local stope extraction. 


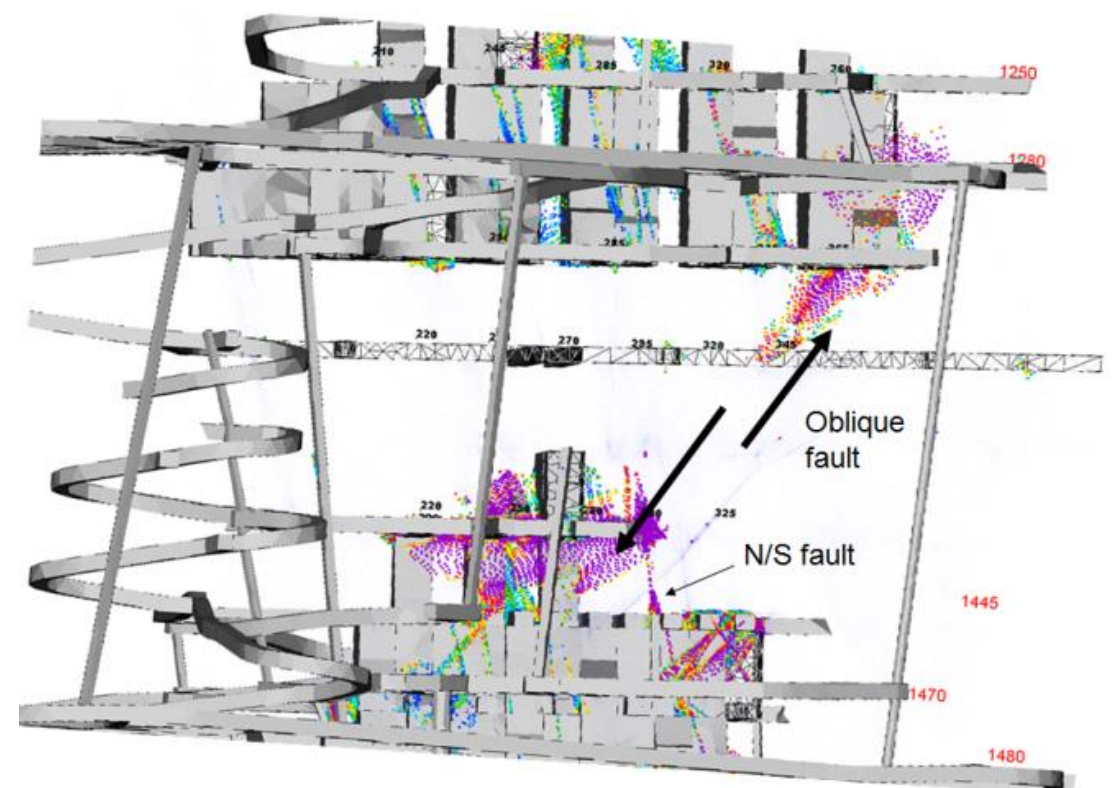

(a)

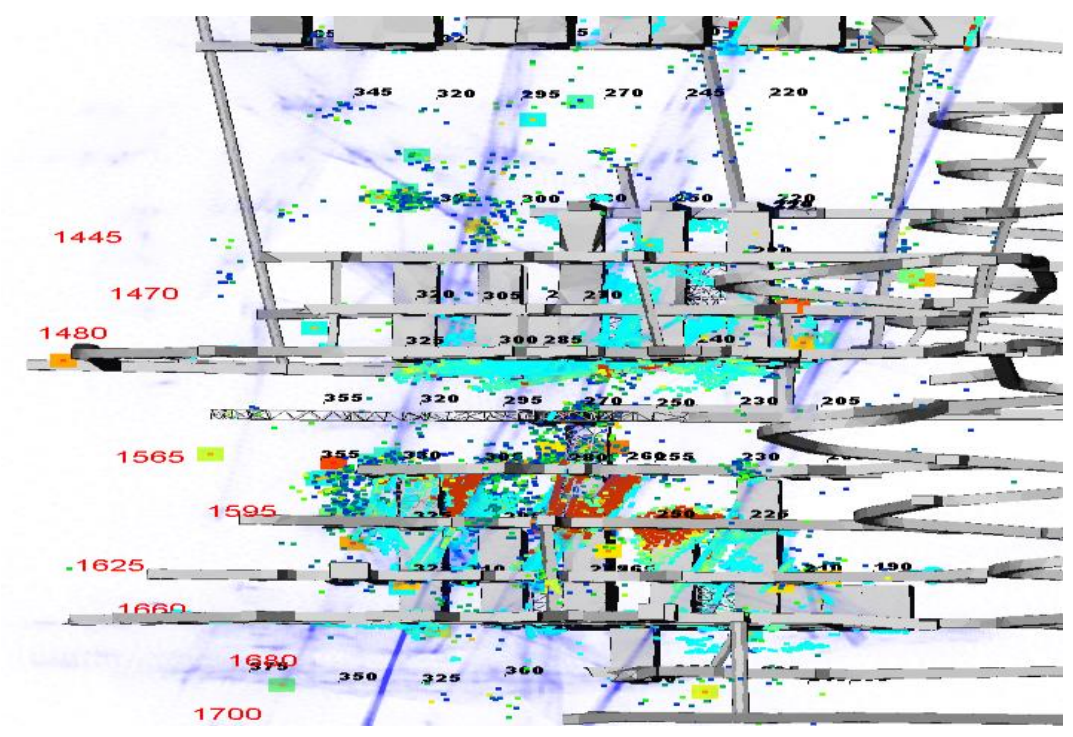

(b)

\section{Figure 20 Output from non-linear model showing fault displacements (a); and energy release on faults (b)}

\section{$7 \quad$ Conclusions}

Nickel Rim South Mine has achieved its' annual production targets and maintained an excellent safety record since the project days and into the full mine operation. The recognition of relatively deep conditions in a structurally complex environment has led to a continuous improvement approach to ground control. In particular the mines seismic array has been an extremely valuable tool to gauge rock mass response to mining. Based on the results achieved (accurate locations with good quality source parameter information) Sudbury Integrated Nickel Operations are re-evaluating how to deploy seismic arrays for future projects. In the Nickel Rim South case, hanging wall and footwall access to a relatively compact orebody was ideal for good spatial distribution of seismic sensors. In many operations, only footwall access is available, often creating relatively planar seismic arrays with limited resolution. New projects with such limitations are being planned with long hole sensor installations to get the array in early and well spatial distributed. 
The seismic monitoring data also clearly shows the impact of the major faulting on how the mine responds. The use of realistic forecasting tools must take the faults into account. To date, the non-linear modelling has been able to make reasonably reliable forecasts for planned ground support enhancements and proactive seismic re-entry protocols (by determining the expected zone of influence of a particular stope blast). Other advanced tools such as geohazmap and mXrap are being used to evaluate geological and seismic risk. The relatively compact orebody with two converging mining fronts (sill pillars) will provide rock mechanics challenges. Ongoing work to improve these analysis techniques remains a key part of the mines ground control program.

The mine design is still considered the most important aspect of maintaining reliable and safe production. The concept of primary/secondary mining at depth has been used elsewhere, and is being successfully implemented at Nickel Rim South. In essence more than half of the mines' reserves are being mined in a stress shadowed state with low local rockburst potential. Just-in-time development is a key component to this success as is the mines ground support strategies.

\section{Acknowledgement}

The authors acknowledge the Sudbury Management Team for permission to publish this paper. In particular the support from Peter Xavier (Mine Director) and Christine Bertoli (Chief Mine Engineer) of Nickel Rim South Mine is greatly appreciated, as is the hard work from Ed Deneka (Ground Control Technician). The mines' geology group and external partners (Dave Beck, John McGaughey, ESG Canada, MS and mXrappers) are also acknowledged for their continued support.

\section{References}

Australian Centre for Geomechanics 2014, mXrap, Australian Centre for Geomechanics, Perth, http://www.mxrap.com.

Beck, D, Levkovitch, V \& Simser, B 2012, 'Explicit dynamic simulation for probabilistic forecasting of fault slip and rock mass seismic potential', in Y Potvin (ed.), Proceedings of the Sixth International Seminar on Deep and High Stress Mining, Australian Centre for Geomechanics, Perth, pp. 373-388.

Hudyma, M 2005, An Introduction to Mine Seismicity, seminar notes, Australian Centre for Geomechanics, Perth.

McGaughey, J 2014, 'A Framework for 4D Quantitative Back-Analysis and Estimation of Geotechnical Hazard Potential in Mines', Proceedings of Geohazards 6, Canadian Geotechnical Society, Richmond.

Mendecki, A 1993, 'Real time quantitative seismology in mines', in RP Young (ed.), Proceedings of the 3rd International Symposium on Rockbursts and Seismicity in Mines, A.A. Balkema, Rotterdam, pp. 287-295.

Simser, B \& Pritchard, C 2010, 'Observational Ground Control at Xstrata's Nickel Rim South Mine, Sudbury, Ontario', Canadian Institute of Mining Operator's Conference, Canadian Institute of Mining, Metallurgy and Petroleum, Westmount.

Simser, B, Jalbout, A \& Pakalnis, R 2014, 'Stability Graph Method for Open Stope Design-Case Histories from Two Sudbury Basin Mines', 1st International Conference on applied empirical design methods in mining, International Society for Rock Mechanics, Lima, proceedings in preparation.

Simser, B 2013, 'Seismic Monitoring at Nickel Rim South Mine', 6th Microseismic Symposium and Workshop, Engineering Seismology Group, Kingston.

Van Aswegen, G \& Butler, AG 1993, 'Applications of quantitative seismology in South African gold mines', in RP Young (ed.), Proceedings of the 3rd International Symposium on Rockbursts and Seismicity in Mines, A.A. Balkema, Rotterdam, pp. 261-266. 